Prepared in cooperation with the National Park Service

\title{
Borehole Analysis, Single-Well Aquifer Testing, and Water Quality for the Burnpit Well, Mount Rushmore National Memorial, South Dakota
}

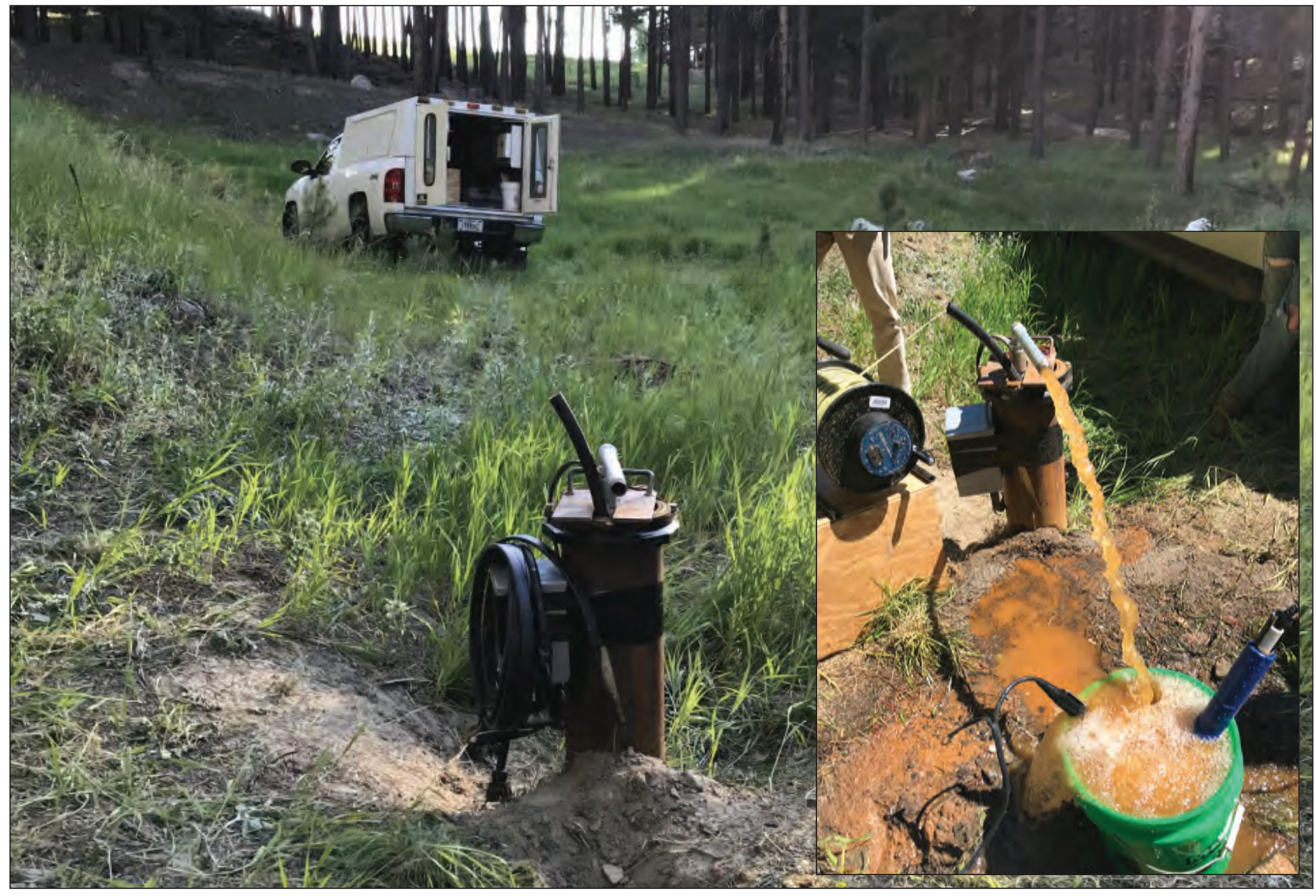

Scientific Investigations Report 2021-5059 
Cover: Photographs showing Burnpit well in Mount Rushmore National Monument, taken June 24, 2020, and (inset) Burnpit well pumping in Mount Rushmore National Monument, taken August 12 , 2020. Photographs by William Eldridge, U.S. Geological Survey. 


\section{Borehole Analysis, Single-Well Aquifer Testing, and Water Quality for the Burnpit Well, Mount Rushmore National Memorial, South Dakota}

By William G. Eldridge, Galen K. Hoogestraat, and Steven E. Rice

Prepared in cooperation with the National Park Service

Scientific Investigations Report 2021-5059 


\section{U.S. Geological Survey, Reston, Virginia: 2021}

For more information on the USGS - the Federal source for science about the Earth, its natural and living resources, natural hazards, and the environment—visit https://www.usgs.gov or call 1-888-ASK-USGS.

For an overview of USGS information products, including maps, imagery, and publications, visit https://store.usgs.gov/.

Any use of trade, firm, or product names is for descriptive purposes only and does not imply endorsement by the U.S. Government.

Although this information product, for the most part, is in the public domain, it also may contain copyrighted materials as noted in the text. Permission to reproduce copyrighted items must be secured from the copyright owner.

Suggested citation:

Eldridge, W.G., Hoogestraat, G.K., and Rice, S.E., 2021, Borehole analysis, single-well aquifer testing, and water quality for the Burnpit well, Mount Rushmore National Memorial, South Dakota: U.S. Geological Survey Scientific Investigations Report 2021-5059, 29 p., https://doi.org/10.3133/sir20215059.

Associated data for this publication:

Eldridge, W.G., and Hoogestraat, G.K., 2021, Borehole video and aquifer test data for the Burnpit well, Mount Rushmore National Memorial, South Dakota, 2020: U.S. Geological Survey data release, https://doi.org/10.5066/ Pg80Z0N9.

U.S. Geological Survey, 2021, USGS water data for the Nation: U.S. Geological Survey National Water Information System database, accessed January 29, 2021, at https://doi.org/10.5066/F7P55KJN.

ISSN 2328-0328 (online) 


\section{Acknowledgments}

The authors wish to acknowledge Rene Ohms, National Park Service, Mount Rushmore National Memorial, for assistance and access to the sites referenced in this study. Additionally, many members of the National Park Service assisted with data collection. Without their assistance, the study would not have been possible. 



\section{Contents}

Acknowledgments ……...................................................................................................................

Abstract



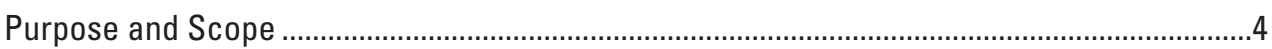

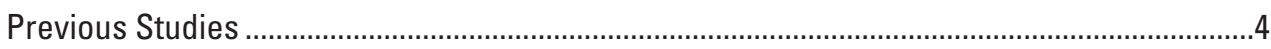

Study Area Description................................................................................................





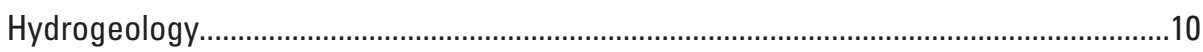

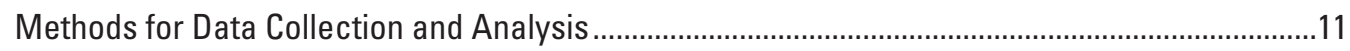

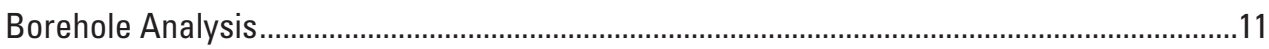



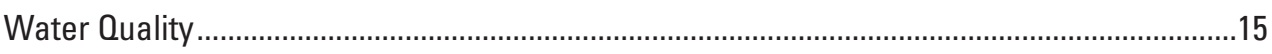

Borehole Analysis, Single-Well Aquifer Testing, and Water Quality ............................................17

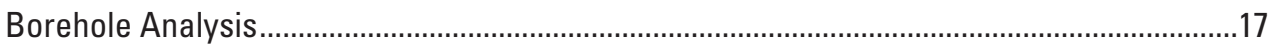

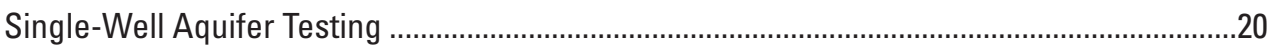

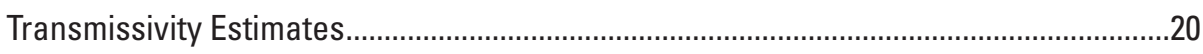

Aquifer Storage Estimates ....................................................................................21

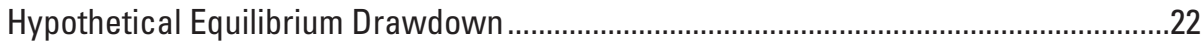

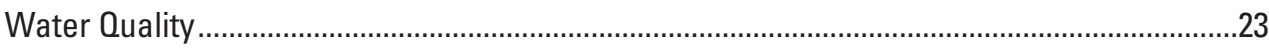

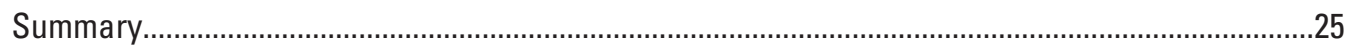



\section{Figures}

1. Map showing study area and geographic features, wells, a borehole, and springs at Mount Rushmore National Memorial, South Dakota, 2021.

2. Graph showing annual precipitation and cumulative difference from annual normal, in inches, at Mount Rushmore National Memorial from 1981 through 2020 observed at National Oceanic and Atmospheric Administration climate station USC00395870 with missing data substituted with daily data from climate station USC00393868

3. Map and cross section showing geology of Mount Rushmore National Memorial..........9

4. Photograph showing the Burnpit well during aquifer testing on June 24,2020 , at Mount Rushmore National Memorial

5. Graph showing time and water-level displacement curves for the National Park Service 2009 and the U.S. Geological Survey 2020 aquifer tests of the Burnpit well, Mount Rushmore National Memorial

6. Images from borehole camera video recorded on June 23 and July 29 of the Burnpit well at Mount Rushmore National Memorial by National Park Service personnel

7. Graphs showing water-level displacement and time with analytical method and curve-matching results for the National Park Service aquifer test completed on August 25, 2009. 
8. Graphs showing water-level displacement and time with analytical method and curve-matching results for the U.S. Geological Survey aquifer test completed on June 24,2020

\section{Tables}

1. Inventory of wells, a borehole, and springs at Mount Rushmore National Memorial, South Dakota, 2021

2. South Dakota water rights permits maintained by the National Park Service at Mount Rushmore National Memorial as of January 2021, listed by priority date

3. Water-level and time data recorded during Burnpit well aquifer tests on August 25, 2009, by the National Park Service and on June 24, 2020, by the U.S. Geological Survey.

4. Input parameter values for the Burnpit well and aquifer characteristics used by AOTESOLV to estimate transmissivity and storage parameters from aquifer-test data collected August 25, 2009, and June 24, 2020, at Mount Rushmore National Memorial

5. Lithologic descriptions of geologic formations of the Burnpit well from the driller well log with depth to the top and bottom of the units from land surface, unit thicknesses, and estimated pumping rate

6. Single-well aquifer-test analytical results from curve-matching techniques applied to the upper and lower zones of the aquifer using early and late pumping data

7. Water-quality data from samples collected at the Burnpit well and relevant standards for comparison, June-July 2020

\section{Conversion Factors}

U.S. customary units to International System of Units

\begin{tabular}{|c|c|c|}
\hline Multiply & By & To obtain \\
\hline \multicolumn{3}{|c|}{ Length } \\
\hline inch (in.) & 2.54 & centimeter $(\mathrm{cm})$ \\
\hline inch (in.) & 25.4 & millimeter (mm) \\
\hline foot $(\mathrm{ft})$ & 0.3048 & meter (m) \\
\hline mile (mi) & 1.609 & kilometer (km) \\
\hline \multicolumn{3}{|c|}{ Area } \\
\hline acre & 4,047 & square meter $\left(\mathrm{m}^{2}\right)$ \\
\hline acre & 0.4047 & hectare (ha) \\
\hline acre & 0.4047 & square hectometer $\left(\mathrm{hm}^{2}\right)$ \\
\hline acre & 0.004047 & square kilometer $\left(\mathrm{km}^{2}\right)$ \\
\hline \multicolumn{3}{|c|}{ Volume } \\
\hline gallon (gal) & 3.785 & liter (L) \\
\hline gallon (gal) & 0.003785 & cubic meter $\left(\mathrm{m}^{3}\right)$ \\
\hline gallon (gal) & 3.785 & cubic decimeter $\left(\mathrm{dm}^{3}\right)$ \\
\hline million gallons (Mgal) & 3,785 & cubic meter $\left(\mathrm{m}^{3}\right)$ \\
\hline
\end{tabular}




\begin{tabular}{lll}
\hline \multicolumn{1}{c}{ Multiply } & \multicolumn{1}{c}{ By } & \multicolumn{1}{c}{ To obtain } \\
\hline \multicolumn{3}{c}{ Flow rate } \\
\hline cubic foot per second $(\mathrm{ft} / \mathrm{s})$ & 0.02832 & cubic meter per second $\left(\mathrm{m}^{3} / \mathrm{s}\right)$ \\
gallon per minute $(\mathrm{gal} / \mathrm{min})$ & 0.06309 & liter per second $(\mathrm{L} / \mathrm{s})$ \\
million gallons per year $(\mathrm{Mgal} / \mathrm{yr})$ & 0.000120 & cubic meter per second $\left(\mathrm{m}^{3} / \mathrm{s}\right)$ \\
\hline \multicolumn{3}{l}{ Specific capacity } \\
\hline gallon per minute per foot $([\mathrm{gal} / \mathrm{min}] / \mathrm{ft})$ & 0.2070 & liter per second per meter $([\mathrm{L} / \mathrm{s}] / \mathrm{m})$ \\
\hline & Transmissivity & \\
\hline foot squared per day $(\mathrm{ft} 2 / \mathrm{d})$ & 0.09290 & meter squared per day $\left(\mathrm{m}^{2} / \mathrm{d}\right)$ \\
\hline
\end{tabular}

International System of Units to U.S. customary units

\begin{tabular}{|c|c|c|}
\hline Multiply & By & To obtain \\
\hline \multicolumn{3}{|c|}{ Length } \\
\hline millimeter (mm) & 0.03937 & inch (in.) \\
\hline
\end{tabular}

Temperature in degrees Celsius $\left({ }^{\circ} \mathrm{C}\right)$ may be converted to degrees Fahrenheit $\left({ }^{\circ} \mathrm{F}\right)$ as follows:

$$
{ }^{\circ} \mathrm{F}=\left(1.8 \times{ }^{\circ} \mathrm{C}\right)+32 \text {. }
$$

Temperature in degrees Fahrenheit ( $\left.{ }^{\circ} \mathrm{F}\right)$ may be converted to degrees Celsius $\left({ }^{\circ} \mathrm{C}\right)$ as follows:

$$
{ }^{\circ} \mathrm{C}=\left({ }^{\circ} \mathrm{F}-32\right) / 1.8 .
$$

\section{Datum}

Vertical coordinate information is referenced to the North American Vertical Datum of 1988 (NAVD 88).

Horizontal coordinate information is referenced to the North American Datum of 1983 (NAD 83).

Elevation, as used in this report, refers to distance above the vertical datum.

\section{Supplemental Information}

Specific conductance is given in microsiemens per centimeter at 25 degrees Celsius $(\mu \mathrm{S} / \mathrm{cm}$ at $\left.25^{\circ} \mathrm{C}\right)$.

Concentrations of chemical constituents in water are given in either milligrams per liter (mg/L) or micrograms per liter $(\mu \mathrm{g} / \mathrm{L})$.

\section{Abbreviations}

EPA U.S. Environmental Protection Agency

NPS National Park Service

USGS U.S. Geological Survey 



\title{
Borehole Analysis, Single-Well Aquifer Testing, and Water Quality for the Burnpit Well, Mount Rushmore National Memorial, South Dakota
}

\author{
By William G. Eldridge, ' Galen K. Hoogestraat,' and Steven E. Rice ${ }^{2}$
}

\section{Abstract}

Mount Rushmore National Memorial (hereafter referred to as "the memorial"), in western South Dakota, is maintained by the National Park Service (NPS) and includes 1,278 acres of land in the east-central part of the Black Hills. An ongoing challenge for NPS managers at the memorial is providing water from sustainable and reliable sources for operations, staff, and the increasing number of visitors. In 2020, the U.S. Geological Survey (USGS) and NPS completed a hydrological study of the Burnpit well (well 5), a 580-foot-deep open hole groundwater well completed in metamorphic (crystalline) rock at the memorial. The purpose of this study was to estimate the geological and hydraulic properties of the aquifer supplying the well and to determine the water quality of the groundwater from the well. The study provides NPS staff and managers background information for assessing future uses for the well. Methods for data collection and analysis for the study included borehole and video camera analysis in 2020, aquifer testing by the NPS in 2009 and the USGS in 2020, and waterquality sampling in 2020.

Borehole camera video generally matched the lithology recorded in the well log. Fractures recorded in the well log and observed with the borehole camera, including more than 20 less prominent fractures and rough sidewall areas, indicated a fractured aquifer. The fractures are the primary conduits for groundwater flow through the rock and into the well.

Transmissivity was estimated for the upper and lower water-level drawdown zones at the Burnpit well with data from the NPS and USGS using the Theis and Cooper-Jacob methods. Transmissivity for the NPS test using the Theis method was 9.0 and 11 feet squared per day $\left(\mathrm{ft}^{2} / \mathrm{d}\right)$ for the upper and lower drawdown zones, respectively. Using the Cooper-Jacob method, the transmissivity was 22 and $14 \mathrm{ft}^{2} / \mathrm{d}$ for the upper and lower drawdown zones of the aquifer, respectively. Transmissivity estimates from data from the USGS test were similar. The Theis method, applied to the upper and lower drawdown zones of the aquifer, produced

\footnotetext{
${ }^{1}$ U.S. Geological Survey.
}

${ }^{2}$ National Park Service. transmissivity estimates of 7.7 and $10 \mathrm{ft}^{2} / \mathrm{d}$, and the CooperJacob method produced estimates of 9.7 and $12 \mathrm{ft}^{2} / \mathrm{d}$, respectively.

Storativity (specific yield) estimated using the Theis method for the NPS aquifer-test data was 0.85 and 0.92 for the upper and lower drawdown zones of the aquifer, respectively. The Cooper-Jacob method applied to the NPS aquifer-test data produced storativity estimates of 0.11 and 0.50 for the upper and lower drawdown zones, respectively. The Theis method applied to the USGS aquifer-test data estimated storativity values of 0.77 and 1.0 for the upper and lower drawdown zones, respectively. The Cooper-Jacob method estimated storativity of 0.50 and 0.60 for the upper and lower drawdown zones of the USGS aquifer test, respectively. The estimated storativity values from the NPS and USGS aquifer tests for the upper and lower drawdown zones were higher than expected for limestones and schists.

The hypothetical equilibrium drawdown for the Burnpit well was estimated after the NPS test in 2009 at no more, and possibly less, than 35 gallons per minute. The NPS noted that the sustainable yield likely was overestimated because the water level did not stabilize during the NPS aquifer test. The specific capacity for the NPS aquifer test in 2009 was 0.16 gallon per minute per foot ([gal $/ \mathrm{min}] / \mathrm{ft})$ of drawdown at 3 hours, and the specific capacity for the USGS aquifer test in 2020 was 0.13 (gal/min)/ft of drawdown at 3 hours. The rate of water-level recovery after pumping ceased was 0.017 and 0.013 (gal/min)/ft for the NPS and USGS aquifer tests, respectively. The water-level recovery rate was nearly an order of magnitude less than the specific capacity estimated during pumping, indicating that water levels in the Burnpit well may not recover quickly enough during pumping to provide for a continuous source of water.

Water-quality samples were collected at the Burnpit well on June 24 and July 23, 2020, and analyzed for field-measured properties, major ions, metals, nutrients, and perchlorate. Iron, zinc, and lithium concentrations for unfiltered samples in the well were at least three times greater than the mean filtered sample concentrations reported for crystalline aquifers in the Black Hills. Manganese concentrations were less than the mean concentration for crystalline aquifers but exceeded the U.S. Environmental Protection Agency (EPA) secondary 
drinking-water standards. The iron concentration from the June 24 sample was about 11 times greater than the EPA secondary drinking-water standards and mean concentrations from crystalline aquifers in the Black Hills. Arsenic concentrations in Burnpit well samples collected in 2020 were greater than the EPA primary drinking-water standard and the mean concentration for crystalline aquifers in the Black Hills. Arsenic occurs naturally in the rock of crystalline aquifers, and concentrations from samples in the Black Hills commonly exceed the EPA primary drinking-water standard of 10 micrograms per liter. High concentrations of arsenic, iron, and manganese metals in the Burnpit well make groundwater from the well in its natural state unusable as a drinking-water source, and water treatment would be necessary to reduce the trace element concentrations to less than the EPA primary and secondary drinking-water standards. However, if the memorial has immediate nonpotable water requirements, such as for construction and fire suppression, groundwater from the Burnpit well could provide water without causing additional stress to current (2021) drinking-water sources.

\section{Introduction}

Mount Rushmore National Memorial (hereafter referred to as "the memorial"), in western South Dakota, is maintained by the National Park Service (NPS) and includes 1,278 acres of land in the east-central part of the Black Hills (fig. 1). In 1925, the U.S. Congress passed legislation allowing sculptures of four former U.S. presidents in the exposed granite on the southeast face of Mount Rushmore. Work on the sculptures began in 1927 and was declared complete in 1941. The number of visitors to the memorial increased from 393,000 in 1941 to more than 2,000,000 in 2020 with a maximum annual attendance of more than 2,400,000 in 2017 (National Park Service, 2020). An ongoing challenge for NPS managers at the memorial is providing water from sustainable and reliable sources for operations, staff, and the increasing number of visitors.

Water use at Mount Rushmore includes drinking water, fire suppression, construction, infrastructure maintenance, equipment cleaning, and concessionaire use. The demand for water to support these uses has increased with time. Between 1968 and 1970, the total water consumed at the memorial was between 6.8 and 7.7 million gallons per year (Powell and others, 1973). In 2016, water pumped from wells reached an annual maximum of about 8.6 million gallons (Molly Davis, National Park Service, written commun., 2021). NPS staff are interested in understanding the hydrogeology, potential production capacity, and water chemistry of existing wells to meet existing and future water demands.
Throughout the history of the memorial, water supplies for operations, staff, and visitors were provided by springs and wells from several sites (table 1, fig. 1). From 1927 to 1967, a cluster of springs named Rushmore Spring (spring 3, fig. 1) was developed to provide water for operational uses (Powell and others, 1973). Several other springs were mapped at the memorial, and Grizzly Bear Spring (spring 6, fig. 1) was developed in the late 1950s to provide water to a campground. In 1950, a 75,000-gallon (gal) water storage reservoir was constructed, and in 1956, a 500,000-gal water storage reservoir was added with distribution lines to gravity feed water from Rushmore Spring to the water treatment plant, pump house, and housing. Wells 1 and 2 and an unnamed borehole near spring 4 (fig. 1) were drilled in 1960 but were not used as water supplies because of low yields and existing water sources from Rushmore Spring were closer to the distribution system (Powell and others, 1973).

Well 3 (referred to by NPS staff as "well 1"; table 1, fig. 1) was completed in July 1967 to a depth of 200 feet (ft) as part of a geologic study. In October 1967, well 3 was integrated into the water production system and began replacing Rushmore Spring as the primary water source. In September 1967, well 4 (fig. 1) was completed to a depth of $500 \mathrm{ft}$ but was never used because of low yield (Powell and others, 1973). A third 125,000-gal reservoir was added to the water storage system in 1978. From 1967 through 2010, well 3 was the primary water source (Hoogestraat and Rowe, 2016), and in 2010, well 6 (referred to by NPS staff as "well 2"; table 1, fig. 1) was completed to a depth of $500 \mathrm{ft}$ to supplement water provided by well 3. The NPS maintains five permits from the South Dakota Department of Environment and Natural Resources for water rights at the memorial with three of the five permits (US596-2, 2588-2, and 2736-2) licensing a total of 0.122 cubic foot per second $\left(\mathrm{ft}^{3} / \mathrm{s}\right.$ ) (about 55 gallons per minute [gal/min]) for water production, and two permits (528-2 and US560-2A) licensing $0.0088 \mathrm{ft}^{3} / \mathrm{s}(4 \mathrm{gal} /$ $\mathrm{min}$ ) for Grizzly Bear Spring and $0.066 \mathrm{ft}^{3} / \mathrm{s}(30 \mathrm{gal} / \mathrm{min})$ for well 1, respectively (table 2; South Dakota Department of Environment and Natural Resources, 2021).

The Burnpit well (well 5; fig. 1) was completed at the memorial in 2008 to a depth of $580 \mathrm{ft}$ in metamorphic (crystalline) rock. The Burnpit well was intended to supplement existing water sources but was not integrated into the water distribution system and has remained unused since construction. In 2020, the U.S. Geological Survey (USGS) and NPS completed a hydrological study of the Burnpit well at the memorial to estimate the geological and hydraulic properties of the aquifer supplying the well and to measure the water quality of the groundwater from the well. The hydrologic study provides NPS staff and managers background information that can be used for assessing future uses for the well. 


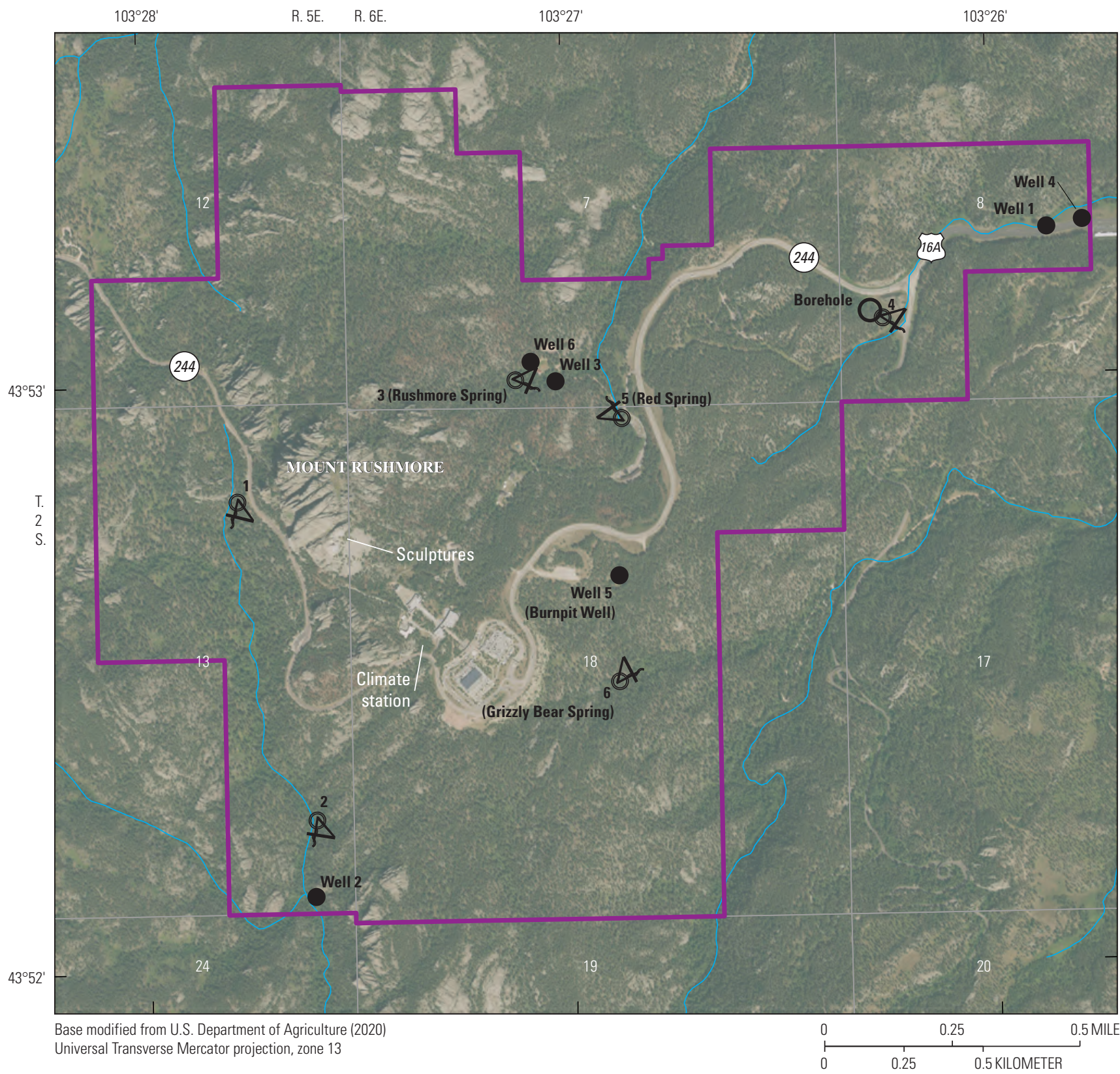

\section{EXPLANATION}

Mount Rushmore National Memorial boundary (study area)

Well 1 Well with label

${ }^{1}$ Spring with label, tail indicates direction of discharge

Borehole

\section{Stream}

8 Public Land Survey System section number

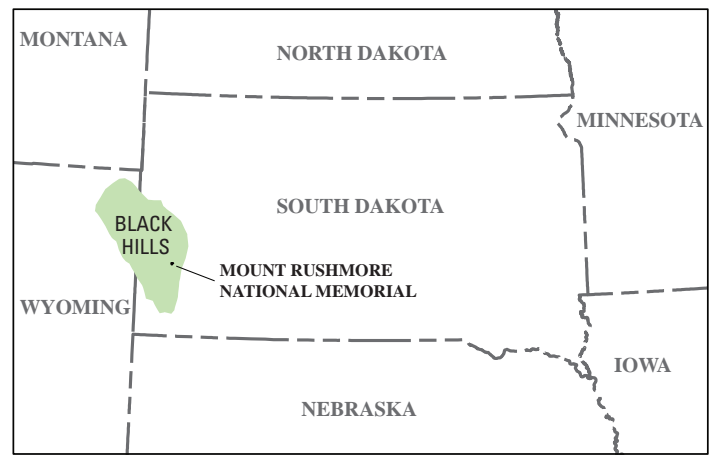

Figure 1. Study area and geographic features, wells, a borehole, and springs at Mount Rushmore National Memorial, South Dakota, 2021. 
Table 1. Inventory of wells, a borehole, and springs at Mount Rushmore National Memorial, South Dakota, 2021.

[USGS, U.S. Geological Survey; NWIS, National Water Information System; gal/min, gallon per minute; (gal/min)/ft, gallon per minute per foot; --, not applicable; in., inch; ft, foot; SD DENR, South Dakota Department of Environment and Natural Resources; NPS, National Park Service]

\begin{tabular}{|c|c|c|c|c|c|c|c|c|}
\hline Site type & $\begin{array}{c}\text { Number } \\
\text { (fig. 1) }\end{array}$ & $\begin{array}{c}\text { USGS NWIS } \\
\text { identification } \\
\text { number }\end{array}$ & Site names ${ }^{1}$ & $\begin{array}{l}\text { Date well } \\
\text { completed }\end{array}$ & Water use & $\begin{array}{c}\text { Well depth } \\
\text { (feet below } \\
\text { land } \\
\text { surface) }\end{array}$ & $\begin{array}{c}\text { Well } \\
\text { diameter } \\
\text { (inches) }\end{array}$ & Aquifer $^{2}$ \\
\hline \multirow[t]{6}{*}{ Well } & 1 & 435230103254501 & $2-6-8-\mathrm{cad} 2$ & July 1960 & Not used & 62.5 & 8 & Alluvium \\
\hline & 2 & 435206103273701 & $2-5-13 \mathrm{ddd}$ & July 1960 & Not used & 58 & 8 & Alluvium \\
\hline & 3 & 435300103265001 & $\begin{array}{l}\text { Well 1; } \\
\quad 2-6-7 \mathrm{cdd} 2\end{array}$ & July 14, 1967 & Production & 200 & 6 & Crystalline rock \\
\hline & 4 & -- & $2-6-8 \mathrm{cad} 1$ & Sept. 8, 1967 & Not used & 500 & 6 & Crystalline rock \\
\hline & 5 & 435240103265301 & Burnpit well & Oct. 29, 2008 & Not used & 580 & $\begin{array}{l}\text { 8-in. for } 42 \\
\quad \text { ft; then } \\
\text { 6-in. } \\
\text { (open } \\
\text { hole) }\end{array}$ & Crystalline rock \\
\hline & 6 & 435302103270501 & Well 2 & June 16, 2010 & Production & 500 & 8 & Crystalline rock \\
\hline Borehole & -- & -- & Test hole & 1960 & Not used & 94 & -- & Crystalline rock \\
\hline \multirow[t]{6}{*}{ Spring } & 1 & -- & $2-5-13$ aac & -- & Not used & -- & -- & -- \\
\hline & 2 & 435215103273501 & $2-5-13 \mathrm{dda}$ & -- & Not used & -- & -- & -- \\
\hline & 3 & 435301103270201 & $\begin{array}{l}\text { Rushmore } \\
\text { Spring; } \\
\text { 2-6-7cdd1 }\end{array}$ & -- & Production & -- & -- & -- \\
\hline & 4 & -- & $2-6-8 \mathrm{ccb}$ & -- & Not used & -- & -- & -- \\
\hline & 5 & -- & $\begin{array}{l}\text { Red Spring; } \\
\text { 2-6-18abb }\end{array}$ & -- & Not used & -- & -- & -- \\
\hline & 6 & 435231103265101 & $\begin{array}{l}\text { Grizzly Bear } \\
\text { Spring; } \\
2-6-18 \mathrm{dbb}\end{array}$ & -- & Not used & -- & -- & -- \\
\hline
\end{tabular}

${ }^{1}$ Site names from Powell and others (1973) or commonly used by NPS staff.

${ }^{2}$ Powell and others (1973) describe crystalline aquifers as metamorphic rock aquifers.

\section{Purpose and Scope}

The purpose of this report is to document the methods, data, and results from borehole analyses; two single-well aquifer tests; and water-quality sampling and analysis of the Burnpit well at the memorial. The scope of the report includes data only for the Burnpit well and does not include data and analyses for the two production wells (wells 3 and 6) in use as of 2021. Borehole analyses used lithologic information from literature, well logs, and images from borehole camera surveys in June and July 2020. Data for the two single-well aquifer tests were collected by the NPS in 2009 and by the USGS in 2020. Water-quality samples were collected in June and July 2020 at the Burnpit well and analyzed for 36 constituents.

\section{Previous Studies}

Powell and others (1973) summarized previous studies completed before 1973 describing geologic features near Mount Rushmore that included Darton $(1901,1918)$, Darton and Paige (1925), and Page and others (1953). Powell and others (1973) also provided an early hydrogeological 


\begin{tabular}{|c|c|c|c|c|c|c|}
\hline $\begin{array}{l}\text { Water level } \\
\text { (feet below } \\
\text { land surface) }\end{array}$ & $\begin{array}{c}\text { Date range of } \\
\text { water-level } \\
\text { measurements }\end{array}$ & $\begin{array}{c}\text { Discharge } \\
\text { rate } \\
\text { (gal } / \mathrm{min} \text { ) }\end{array}$ & $\begin{array}{l}\text { Date of discharge } \\
\text { measurements }\end{array}$ & $\begin{array}{c}\text { Specific } \\
\text { capacity } \\
\text { ([gal/min]/ft) }\end{array}$ & $\begin{array}{l}\text { Relative yield } \\
\text { (gal/min) }\end{array}$ & References \\
\hline $4.5-9.5$ & $\begin{array}{l}\text { Dec. 1966-May } \\
1968\end{array}$ & -- & -- & -- & $29-30$ & $\begin{array}{l}\text { Powell and others, } \\
\text { 1973; SD DENR, } \\
2021\end{array}$ \\
\hline $2.1-3.6$ & $\begin{array}{l}\text { Dec. 1966-May } \\
1968\end{array}$ & -- & -- & -- & -- & $\begin{array}{l}\text { Powell and others, } \\
1973\end{array}$ \\
\hline Flowing & $\begin{array}{l}\text { July 1967-May } \\
1968\end{array}$ & 11 & Aug. 14, 1967 & 1.74 & $\begin{array}{l}50 \text { (for } 10-12 \\
\text { hours) }\end{array}$ & $\begin{array}{l}\text { Powell and others, } \\
1973\end{array}$ \\
\hline $4.8-7.5$ & $\begin{array}{l}\text { Sept. 1966-May } \\
\quad 1968\end{array}$ & -- & -- & 0.38 & $\begin{array}{l}\text { 25-30 (for 10-12 } \\
\text { hours) }\end{array}$ & $\begin{array}{l}\text { Powell and others, } \\
1973\end{array}$ \\
\hline $5.87-30.0$ & $\begin{array}{l}\text { Aug. 2009- } \\
\text { June } 2020\end{array}$ & -- & -- & $\begin{array}{l}0.13-0.16 \\
\text { (for } 3 \\
\text { hours) }\end{array}$ & $\begin{array}{l}\text { 50-55 (for } 8 \\
\text { hours); } 35 \text {, or } \\
\text { less, gal/min } \\
\text { sustained }\end{array}$ & $\begin{array}{l}\text { SD DENR, 2020; } \\
\text { Larry Martin, NPS, } \\
\text { written commun., } \\
2009\end{array}$ \\
\hline 22.0 & June 2010 & -- & -- & -- & -- & SD DENR, 2020 \\
\hline-- & -- & -- & -- & -- & -- & $\begin{array}{l}\text { Powell and others, } \\
1973\end{array}$ \\
\hline-- & -- & 5 & 1967 & -- & -- & $\begin{array}{l}\text { Powell and others, } \\
1973\end{array}$ \\
\hline-- & -- & 1 & 1967 & -- & -- & $\begin{array}{l}\text { Powell and others, } \\
1973\end{array}$ \\
\hline-- & -- & $20 ; 13.5$ & $1967 ; 1995$ & -- & -- & $\begin{array}{l}\text { Powell and others, } \\
\text { 1973; USGS, } 2021\end{array}$ \\
\hline-- & -- & 1 & 1967 & -- & -- & $\begin{array}{l}\text { Powell and others, } \\
1973\end{array}$ \\
\hline-- & -- & 7 & 1967 & -- & -- & $\begin{array}{l}\text { Powell and others, } \\
1973\end{array}$ \\
\hline-- & -- & 4 & 1967 & -- & -- & $\begin{array}{l}\text { Powell and others, } \\
1973\end{array}$ \\
\hline
\end{tabular}

investigation of the memorial that included assessments of existing water supplies and suggestions for future water supplies. Geologic maps of the Black Hills that included Mount Rushmore were completed by DeWitt and others (1989), Driscoll and others (2002), and Redden and DeWitt (2008). Redden and others (2016) published a geologic map and cross sections specific to the Mount Rushmore area. The USGS completed hydrologic studies of the Black Hills from 1990 through 2002 and summarized findings in Carter and others (2002) and Driscoll and others (2002). The NPS completed a geologic resource evaluation report of the memorial in 2008
(Graham, 2008). From 2011 to 2015, Hoogestraat and Rowe (2016) investigated perchlorate and selected metals in wells, springs, surface waters, and soils at the memorial.

\section{Study Area Description}

The study area included the Burnpit well (well 5) in the memorial in the east-central part of the Black Hills in South Dakota (fig. 1). Land surface elevation in the memorial boundary ranges from 4,420 to 5,725 ft above the North American Vertical Datum of 1988 at the summit of Mount Rushmore. 
Table 2. South Dakota water rights permits maintained by the National Park Service at Mount Rushmore National Memorial as of January 2021, listed by priority date (South Dakota Department of Environment and Natural Resources, 2021).

[ft $\mathrm{ft}^{3} \mathrm{~s}$, cubic foot per second; Mt., Mount; ft, foot; gal/min, gallon per minute]

\begin{tabular}{|c|c|c|c|c|c|c|}
\hline $\begin{array}{l}\text { Permit number } \\
\text { (South Dakota } \\
\text { Department of } \\
\text { Environment and } \\
\text { Natural Resources, } \\
\text { 2021) }\end{array}$ & $\begin{array}{l}\text { Applicable site } \\
\text { (table 1) }\end{array}$ & Permit status & $\begin{array}{l}\text { Permitted } \\
\text { discharge } \\
\left(\mathrm{ft}^{3} / \mathrm{s}\right)\end{array}$ & Date permit approved & $\begin{array}{l}\text { Water right } \\
\text { priority date }\end{array}$ & Permit notes \\
\hline US596-2 & $\begin{array}{l}\text { Spring } 3 \text { (Mt. } \\
\text { Rushmore Spring) }\end{array}$ & Licensed & 0.03 & July 19, 1949 & June 11, 1949 & $\begin{array}{l}\text { Water uses described in the permit application } \\
\text { include domestic, recreational, and fire protec- } \\
\text { tion. Permit application mentions a water project } \\
\text { completed in October } 1938 \text { to divert water from a } \\
\text { spring to a 36,500-gallon storage reservoir. }\end{array}$ \\
\hline $528-2$ & $\begin{array}{l}\text { Spring } 6 \text { (Grizzly } \\
\text { Bear Spring) }\end{array}$ & Licensed & 0.0088 & June 17, 1959 & March 28, 1959 & $\begin{array}{l}\text { Water uses in the permit application include fire } \\
\text { protection, public recreation, and a restaurant. } \\
\text { The permit describes water system construction } \\
\text { completed on May 15, 1959, that included a con- } \\
\text { crete collector basin and three infiltration laterals } \\
\text { installed } 18 \text { inches below land surface with an } \\
80 \text {-ft length. The water system was planned for } \\
\text { use by a campground. }\end{array}$ \\
\hline US560-2A & Well 1 (groundwater) & Licensed & 0.066 & September 27, 1961 & May 11, 1961 & $\begin{array}{l}\text { Water uses in the permit include resort and conces- } \\
\text { sion operations, domestic, fire protection, and } \\
\text { landscaping. The well was completed on July 27, } \\
\text { 1960, with depth of } 61 \mathrm{ft} \text { and a 6-inch casing. The } \\
\text { well pump was installed on August 10, 1961, with } \\
\text { an expected yield of } 30 \mathrm{gal} / \mathrm{min} \text {. The well is } 150 \mathrm{ft} \\
\text { from the east boundary. }\end{array}$ \\
\hline $2588-2$ & Well 3 (groundwater) & $\begin{array}{l}\text { Incorporated } \\
\text { with permit } \\
2736-2\end{array}$ & 0.07 & September 5, 2006 & May 11, 2006 & $\begin{array}{l}\text { The permit amends permit US596-2 by changing the } \\
\text { diversion location from spring } 3 \text { to well } 3 \text { and by } \\
\text { appropriating an additional } 31 \text { gal/min. Water uses } \\
\text { include recreation and commercial. The well was } \\
\text { drilled in July } 1967 \text { to a depth of } 200 \mathrm{ft} \text { and began } \\
\text { service in October } 1967 \text {. The permit describes a } \\
500,000 \text {-gallon storage tank added to the distribu- } \\
\text { tion system in } 1957 \text {. Surface water use as a water } \\
\text { source was discontinued in October } 1967 \text {. Permit } \\
\text { documentation concluded that well } 3 \text { and spring } \\
\text { waters were the same waters supplied by the same } \\
\text { aquifer contained in Proterozoic-age crystalline } \\
\text { rocks. }\end{array}$ \\
\hline $2736-2$ & Well 6 (groundwater) & Licensed & 0.022 & March 16, 2015 & January 2, 2015 & $\begin{array}{l}\text { The permitted source of water was from well } 6 \text { with } \\
\text { a depth of } 500 \mathrm{ft} \text {, and the permit amends permit } \\
2588-2 \text { with an additional appropriation of } 10 \\
\text { gal } / \mathrm{min} \text {, which was the difference between the } \\
\text { authorized } 45 \mathrm{gal} / \mathrm{min} \text { and the pump capacity of } \\
55 \mathrm{gal} / \mathrm{min} \text {. }\end{array}$ \\
\hline
\end{tabular}


South Dakota State Highway 244 provides access to the memorial and extends from the easternmost border to the northwest corner of the memorial boundary. The NPS oversees administrative buildings, visitor areas, a large parking facility, hiking paths, and the sculpture on the southeast side of Mount Rushmore.

\section{Climate}

Climate in the Black Hills area is continental with generally low precipitation, hot summers, cold winters, and extreme variations in precipitation and temperature (Driscoll and others, 2002). Mean annual precipitation at the memorial reported by the National Oceanic and Atmospheric Administration from 1981 to 2010 was about 21.5 inches (in.; National Oceanic and Atmospheric Administration climate station USC00395870, Mount Rushmore National Memorial, South Dakota, United States; National Oceanic and Atmospheric Administration, 2020; fig. 1). Annual precipitation from 1981 to 2020 at Mount Rushmore ranged from about 11.2 in. (in 1985) to about 39.0 in. (in 2019; fig. 2). Precipitation was generally less than normal in the 1980s and early 1990s, greater than normal in the late 1990s, less than normal in the early 2000s, and normal or greater than normal in the late 2000s and 2010s (fig. 2). The cumulative difference from annual normal increased nearly 40 in. from 1994 to 1999 and more than 40 in. from 2009 to 2019 (fig. 2).

Cumulative differences in annual normal precipitation may correlate to groundwater-level trends measured in wells completed in unconfined or semiconfined aquifers. The positive correlation between precipitation and groundwater levels occurs because precipitation can be the primary recharge source for unconfined aquifers (Anderson and others, 2019). Therefore, wells completed in unconfined aquifers near Mount Rushmore would be expected to have lower water levels in the early 1990s and mid- to late 2000s and relatively higher water levels in the late 1990s and 2009 through 2020. Additionally, the same pattern would be expected for seasonal changes, with water levels lower during the drier months of the year and higher during the wetter months of the year; however, continuous water-level and spring-flow data were not available to demonstrate the correlation for Mount Rushmore wells and springs.

\section{Geologic Setting}

The geologic setting at the memorial includes rocks from igneous and metamorphic events (Powell and others, 1973). The western part of the memorial, including the sculpture, is composed mostly of granite (fig. 3). The eastern part of the memorial is composed mostly of granite and schists (fig. 3). Quartz veins, dikes, and sills consisting of pegmatites are abundant in the eastern part of the memorial (Powell and others, 1973). Lithologic logs from wells and a borehole completed near Mount Rushmore record bodies of granite and pegmatite at various depths (South Dakota Department of Environment and Natural Resources, 2020). Unconsolidated alluvial deposits derived from streams and drainages weathering the consolidated rock overlie the igneous and metamorphic rocks. The origin of the rocks, description of the topography, and discussion of geologic structures at Mount Rushmore are described in Powell and others (1973). Summary descriptions of the geologic material composing the local groundwater aquifers are provided in this section from youngest to oldest.

Quaternary alluvium deposits are in the northeastern part of the memorial along ephemeral stream drainages (fig. 3). The deposits consist of unconsolidated to poorly consolidated rock with clasts of as much as boulder-sized Proterozoic-aged rock (Redden and others, 2016) that are mostly schist fragments with lesser amounts of granite and pegmatite (Powell and others, 1973). Wells 1 and 2 were completed in alluvium with depths of about 62 and $58 \mathrm{ft}$ below land surface, respectively (table 1; South Dakota Department of Environment and Natural Resources, 2020). The lithologic log for well 1 reported that soft bedrock may have been detected at $37 \mathrm{ft}$ below land surface and noted that the alluvial material was from weathered quartz-muscovite schist (South Dakota Department of Environment and Natural Resources, 2020).

Granitic rocks at the memorial are early Proterozoicaged (about 1.715 billion years ago) Harney Peak Granite (Redden and others, 2016). The Harney Peak Granite is fine grained to pegmatitic. Sills, dikes, and large bodies of granite are throughout the rock in the memorial (fig. 3). The dominant minerals in the Harney Peak Granite include perthitic microcline, oligoclase, quartz, and muscovite and accessory minerals include tourmaline, biotite, and garnet (Redden and others, 2016). The sculpture at the memorial and most surficial features in the west consist of Harney Peak Granite (fig. 3; Powell and others, 1973).

Several types of Proterozoic-aged metamorphic rock are exposed at the memorial including metagraywackes, metabasalts, schists, carbonate facies, and biotite schists (fig. 3). Metagraywacke units 1 and 2 are exposed at the land surface and consist of quartz-mica schists and phyllites that are tan and greenish gray to gray (unit 2) or tan and gray to black (unit 1; Redden and others, 2016). Metagraywacke unit 2 is in the east and metagraywacke unit 1 is in the central and western parts of the memorial (fig. 3). Metabasalt units are present as thin outcrops in the center of the memorial and are composed of pale-green to dark-gray or green amphibolites that are finely crystalline (fig. 3). Schist, quartzite, and metaconglomerate with large quartzite clasts of as much as $3 \mathrm{ft}$ also are detected in the center of the memorial (fig. 3). A thin unit of carbonate facies iron formation with iron-stained metachert and carbonaceous phyllite is present at a narrow outcrop near the center of the memorial as an interflow deposit about 0.2 mile (mi) east of well 3 and 0.1 mi east of the Burnpit well. A unit of Proterozoic-aged biotite-garnet schist and biotite schist is exposed in the southwestern part of the memorial (fig. 3) and is composed of graphitic schist and phyllite with garnet- and biotite-rich layers and massive quartzose beds (Redden and 


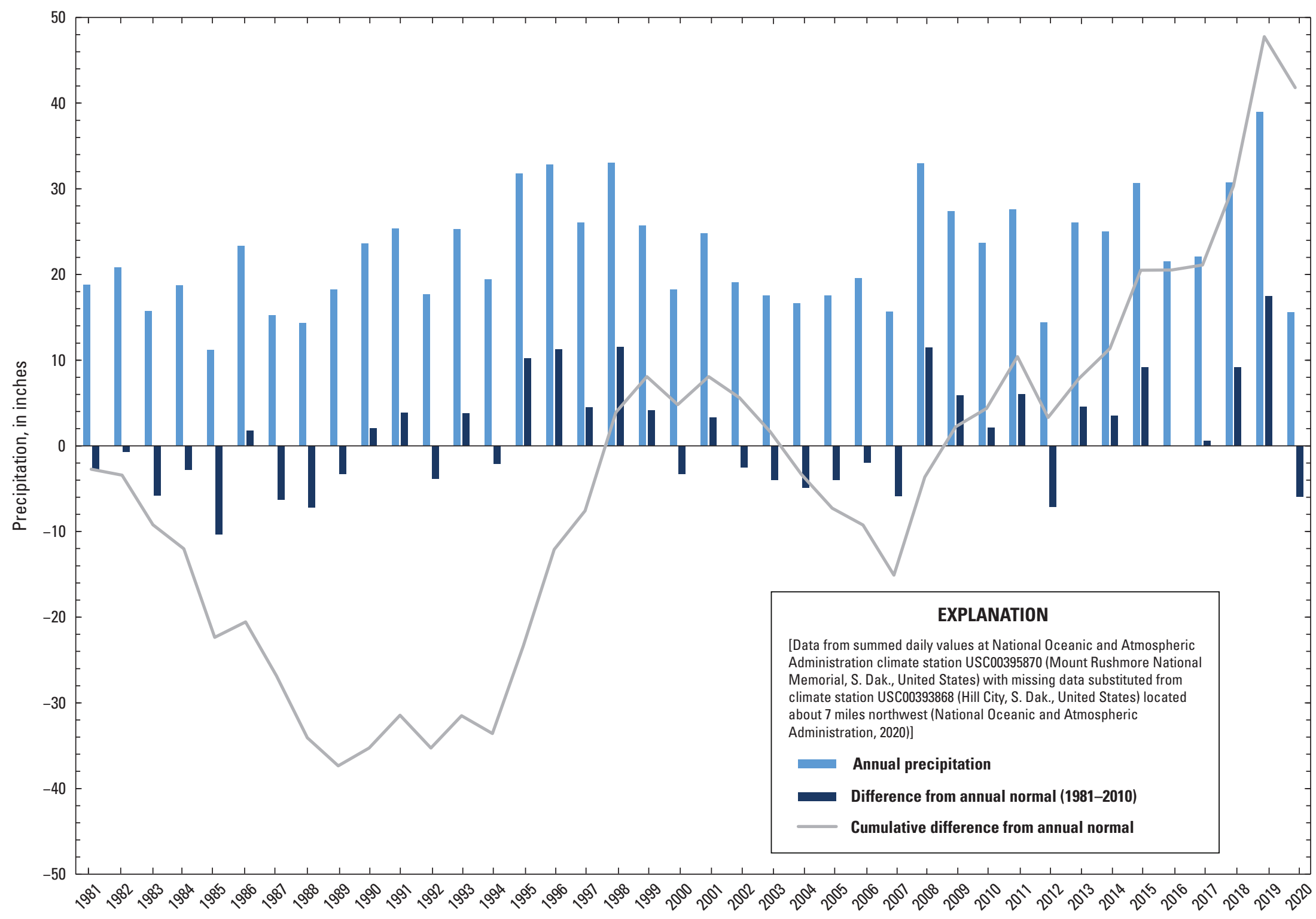

Year

Figure 2. Annual precipitation and cumulative difference from annual normal, in inches, at Mount Rushmore National Memorial from 1981 through 2020 observed at National Oceanic and Atmospheric Administration climate station USC00395870 (Mount Rushmore National Memorial, South Dakota. United States) with missing data substituted with daily data from climate station USC00393868 (Hill City, South Dakota, United States; National Oceanic and Atmospheric Administration, 2020). 

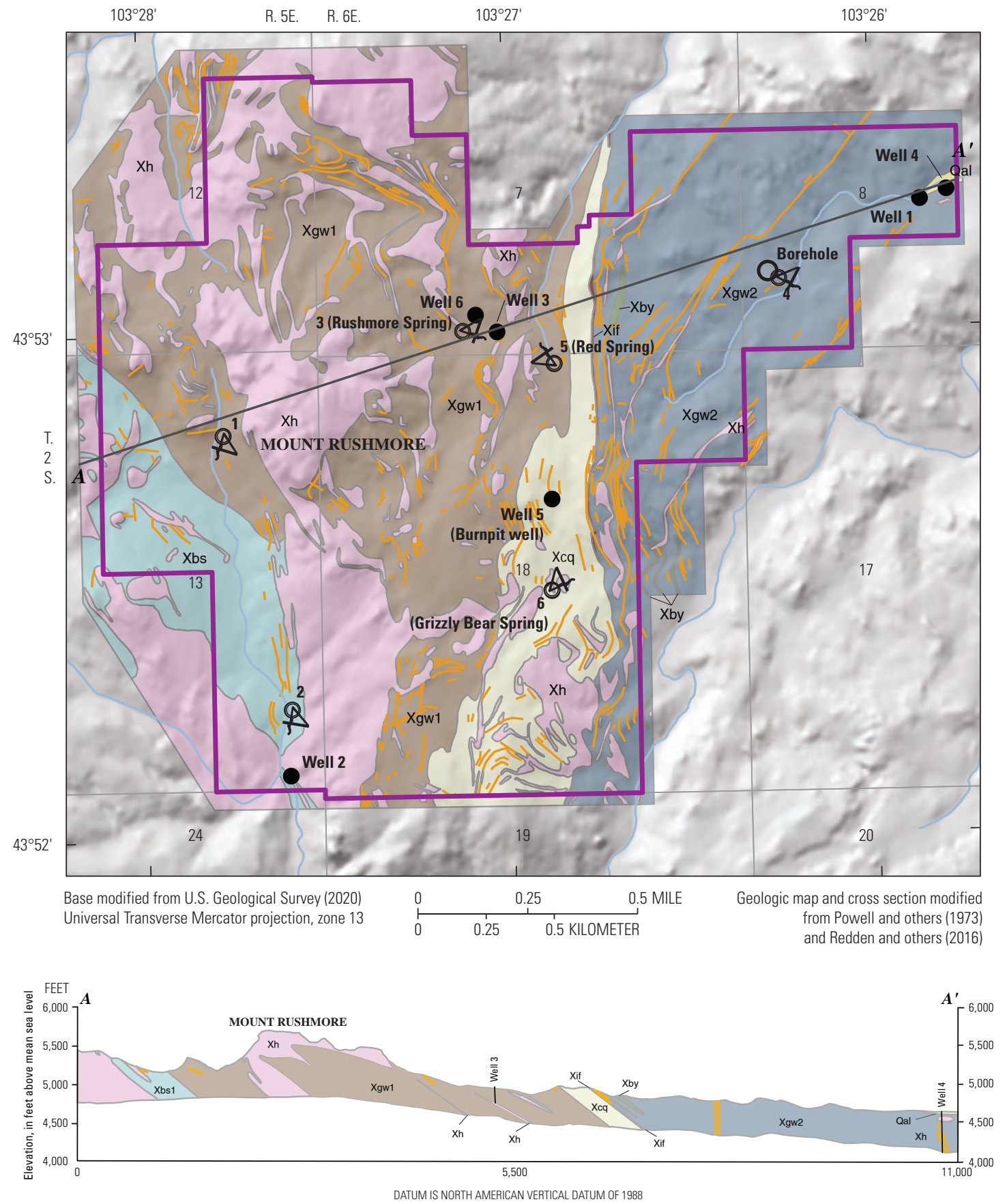

\section{EXPLANATION}

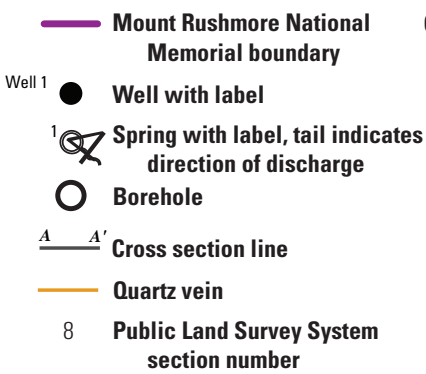

Geologic unit (modified from Redden and others, 2016)

Qal Alluvium-Unconsolidated to poorly consolidated; clasts to boulder size of Proterozoic lithologies

Harney Peak Granite-Fine grained to pegmatic; typically layered; occurs as sills and dikes to large bodies; some are zoned; age 1.715 billion years

Metagraywacke unit 2-0uartz-mica schist and pyllite; tan, greenish gray, to gray; variously bedded Metabasalt-Pale-green to dark-gray or green amphibolite; typically finely crystalline

Xcq Schist, quartzite, and metaconglomerate-Clasts as much as 3 feet across of quartzite; gray, dark gray, tan

Xif Carbonate facies iron formation-Iron-stained metachert, and cabonaceous pyllite as interflow deposits

Xgw1 Metagraywacke unit 1-Quartz-mica schist, mica schist, and phyllite; tan, gray, to black; variously bedded

Xbs Biotite-garnet schist and biotite schist-Graphitic schist and phyllite with garnet- and biotite-rich layers and massive quartzose beds

Figure 3. Geology of Mount Rushmore National Memorial (modified from Powell and others, 1973; Redden and others, 2016). 
others, 2016). Quartz veins, some with surface exposures exceeding $0.5 \mathrm{mi}$ in length, are in metagraywacke units 1 and 2, as well as in the schist, quartzite, and metaconglomerate metamorphic units (fig. 3). Quartz veins also are reported in well logs several hundred feet below land surface (South Dakota Department of Environment and Natural Resources, 2020). The thickness of the quartz veins reported in well logs at the Burnpit well ranges from 18 to $40 \mathrm{ft}$ (South Dakota Department of Environment and Natural Resources, 2020).

\section{Hydrogeology}

The hydrogeology of the memorial includes localized and noncontinuous aquifers composed of unconsolidated Quaternary alluvial deposits and consolidated Proterozoic igneous and metamorphic bedrock (Powell and others, 1973; Hoogestraat and Rowe, 2016). Groundwater in the alluvial aquifers is affected by the hydrologically connected stream waters in the drainages of the memorial. The volume of groundwater in the alluvial aquifers depends on the discharge and stage of the streams overlying the aquifers. Powell and others (1973) provided detailed descriptions of the alluvial aquifers and evaluated their potential as future water supplies.

Aquifers in the Proterozoic igneous and metamorphic rocks of the Black Hills generally are referred to as crystalline aquifers. In the Black Hills, crystalline rocks are the oldest geologic units and regionally form a basement under the local Paleozoic, Mesozoic, and Cenozoic rocks and sediments (Williamson and Carter, 2002). Crystalline rock generally has low permeability and forms the lower confining unit for the sedimentary aquifers in the Black Hills. Localized aquifers in exposed crystalline rock generally have a small spatial extent and are common in the central core of the Black Hills, including the memorial, where enhanced secondary permeability in the rock results from weathering and fracturing (Carter and others, 2002).

The volume and flow characteristics of groundwater in aquifers composed of Proterozoic igneous and metamorphic bedrock are affected by fractures and intrusions in the rock. The amount of groundwater available locally depends on the volume of fractured rock in the subsurface at the location (Powell and others, 1973). In crystalline aquifers of the Black Hills, water-table (unconfined) conditions generally prevail where fractures in the rock are saturated and topography affects groundwater-flow directions (Carter and others, 2002; Driscoll and others, 2002). Fractures created by intrusion of pegmatitic dikes and sills into mica schists and other metamorphic rock allow groundwater to feed springs in the central part of the memorial (springs 3, 5, and 6; fig. 1). The fractures also are likely responsible for the more productive aquifers in the central part of the memorial compared to the metagraywacke and schist units in the eastern part of the memorial that do not provide ideal conditions for productive aquifers (Powell and others, 1973).
Local precipitation provides the primary recharge to aquifers in the memorial (Powell and others, 1973). Fractures and joints in the Proterozoic granite and pegmatite rock of the crystalline aquifers rapidly transmit large quantities of recharged water to the wells and springs in the north-central part of the memorial, including well 3, well 6, and Rushmore Spring (Powell and others, 1973; fig. 1). Recharge to the crystalline aquifers also may result from high infiltration rates from permeable surficial deposits (Rahn, 1990). Powell and others (1973) estimated that a mean annual precipitation of 19 in. provides enough recharge to maintain springflow, streamflow, and well production for the memorial; however, mean annual precipitation of less than $15 \mathrm{in}$. could reduce spring discharge, cause streamflow to cease, and lower well productivity. Total annual precipitation of less than 15 in. was recorded only three times (1985, 1988, and 2012) from 1981 to 2020 (fig. 2). The actual effect of low precipitation in those years is unknown because continuous water-level and springflow data are not available for those years.

Groundwater-level data for aquifers in the memorial are sparse. Powell and others (1973) reported water levels from the mid-1960s through May 1968 at wells 1-4 (table 1). Water levels at wells 1, 2, and 4 ranged from 2.1 to $9.5 \mathrm{ft}$ below land surface during that time, and well 3 was reported as flowing above the land surface from July 1967 through May 1968 (table 1). The flowing artesian conditions at well 3 indicate that the well could be completed in a semiconfined aquifer or that granite or pegmatite sills, acting to confine groundwater flow, cause upwelling of water near well 3 (Powell and others, 1973). The water level was measured at the Burnpit well after the completion of drilling on October 29, 2008, at $30.0 \mathrm{ft}$ below land surface (South Dakota Department of Environment and Natural Resources, 2020), and on August 24, 2009, the NPS reported a water level of about $30 \mathrm{ft}$ below land surface. On June 6 and 24, 2020, water levels recorded by the USGS at the Burnpit well were 8.04 and $5.87 \mathrm{ft}$ below land surface, respectively, and on July 23, 2020, the USGS measured a water level at $20.45 \mathrm{ft}$ below land surface (U.S. Geological Survey, 2021).

The pattern of generally increasing water levels at the Burnpit well from 2008 to 2020 correlates with the increase in cumulative difference from annual normal precipitation from 2008 to 2020 (fig. 2). The cumulative difference from annual normal precipitation increased from -3.7 to 41.8 in. from 2008 through 2020, which corresponds to increased water levels at the Burnpit well from about $30.0 \mathrm{ft}$ below land surface to $5.87 \mathrm{ft}$ below land surface during the same time. The positive correlation between precipitation and groundwater levels at the Burnpit well indicates that the well is recharged primarily by precipitation.

Groundwater-quality conditions of crystalline aquifers in the Black Hills area of South Dakota were summarized by Williamson and Carter (2002), Putnam and others (2008), and South Dakota Mines (2021). Water-quality conditions of crystalline aquifers, referred to as Precambrian aquifers in Williamson and Carter (2002) within and near the memorial, 
are affected by the bedrock mineralogy, climatic variability (wet and dry cycles), and human sources of contaminants. In general, groundwater from the nearby limestone aquifers in the Black Hills has greater hardness, alkalinity, and total dissolved solids than the crystalline aquifers in the core of the Black Hills because the dissolution of limestone and dolomite occurs more rapidly than dissolution of minerals in the crystalline bedrock. Crystalline aquifers generally have higher concentrations of trace elements (such as iron, manganese, and arsenic) than the limestone aquifers in the Black Hills and generally have a small, localized spatial extent (Williamson and Carter, 2002).

\section{Methods for Data Collection and Analysis}

Methods for data collection and analysis to determine the geological and hydraulic properties of the aquifer supplying the Burnpit well, and the water quality of the groundwater from the well, included borehole and video camera analysis in 2020, aquifer testing by the NPS in 2009 and the USGS in 2020 , and water-quality sampling in 2020. Borehole analysis used data from well logs and borehole camera video to document rock fractures that could facilitate groundwater flow to the well and to determine the analytical method for aquifer-testing analysis. Single-well aquifer tests by the NPS in 2009 and the USGS in 2020 for the Burnpit well estimated hydraulic properties of the aquifer by comparing water-level data from the aquifer test to theoretical curves from analytical solutions for idealized aquifers. Aquifer tests also provided data on the maximum sustainable pumping rate of the well. Data associated with the borehole video and aquifer testing are provided in a USGS data release (Eldridge and Hoogestraat, 2021). Water-quality data from the Burnpit well were analyzed by recording groundwater field properties, collecting water samples for laboratory chemical analysis, and comparing the results to drinking-water standards and mean concentrations for crystalline aquifers in the Black Hills. Water-quality results are recorded in the USGS National Water Information System database (U.S. Geological Survey, 2021) and can be accessed using the USGS site identification number for the Burnpit well (435240103265301; table 1).

\section{Borehole Analysis}

Borehole analysis at the Burnpit well was completed by examining well logs and downward-looking borehole camera video. The well log for the Burnpit well recorded well construction information and geologic lithology (South Dakota Department of Environment and Natural Resources, 2020). Data from the well log lithology were manually correlated to images from the borehole camera video.
The purpose of the borehole camera video analysis was to observe rock fractures that could facilitate groundwater flow to the well and to determine the optimal analytical method for aquifer-testing analysis. Rock fractures were visible because the well is cased only at the top $40 \mathrm{ft}$, and the remaining $540-\mathrm{ft}$ well depth is an open hole without any casing. Video of the well casing and borehole of the Burnpit well was recorded by NPS personnel using an Allegheny Instruments Heavy Duty GeoVision Nano Camera system (Allegheny Instruments, 2021). The camera was downward looking, which limited the view of the borehole sidewalls containing fractures; however, fractures were observed despite the limited sidewall view. The camera system was suspended on a $650-\mathrm{ft}$ cable and lowered into the well on June 23 and July 29, 2020. The depth below land surface recorded by the camera system could be inaccurate by as much as $2 \mathrm{ft}$ because the depth counter on the camera system was started between the top of the casing and the land surface, which was a distance of about $2 \mathrm{ft}$. The borehole video data recorded on June 23 included well depths below land surface from about 0 to $98 \mathrm{ft}$ and from 220 to $250 \mathrm{ft}$ and at a stationary depth of $256 \mathrm{ft}$. The video was not continuous because of operational errors, and additional video was recorded on July 29. Borehole video data recorded on July 29 were collected continuously from 0 to about $533 \mathrm{ft}$ below land surface. The full depth of the well was not recorded because high sediment concentrations starting at about $520 \mathrm{ft}$ below land surface decreased the video quality and the well borehole was not clearly visible.

\section{Single-Well Aquifer Testing}

Single-well aquifer tests were completed at the Burnpit well on August 25, 2009, by the NPS and on June 24, 2020, by the USGS. A single-well aquifer test estimates hydraulic properties of an aquifer by comparing the water-level change curve, caused by pumping from a single well, to theoretical curves from analytical solutions of idealized aquifers (Stallman, 1978; Schaap, 2000). Both tests were similar in design; both manually recorded water-level measurements at various time intervals before, during, and after pumping using electric water-level measurement tapes (electric tape). Singlewell testing was necessary because observation wells do not exist in the study area. Manual measurements were used because the in-well pumping equipment did not allow enough space to suspend a transducer. A monitor tube was installed temporarily in 2020; however, the transducer data were unusable because the transducer became stuck at a tubing joint at a depth of about $180 \mathrm{ft}$ below land surface and blocked the flow of water in the tube.

During well construction in 2008, the drilling contractor noted that the bottom $100 \mathrm{ft}$ of the well were drilled through hard gray schist that did not produce any appreciable amount of water, and water-bearing fractures did not exist deeper than $485 \mathrm{ft}$ below land surface. The contractor installed the pump, a Grundfos 40S100-30 with a 10-horsepower motor, at a depth 
of $504 \mathrm{ft}$ below land surface. After installation, the contractor tested the pump and reported a pumping rate of $150 \mathrm{gal} / \mathrm{min}$ reduced the water level in the well to the depth of the pump; however, the contractor completed another test using a pumping rate of about $55 \mathrm{gal} / \mathrm{min}$ that resulted in a stable water level at about $460 \mathrm{ft}$ below land surface for 8 hours.

The single-well aquifer test at the Burnpit well on August 25, 2009, was completed by the NPS about 1 year after the well was drilled on October 29, 2008. The purpose of the test was to determine the maximum pumping rate that the well could sustain to provide a steady source of groundwater. The test also facilitated water-quality sampling of the groundwater in the well by purging the well for several hours before sample collection. During the 2009 NPS aquifer test, water-level drawdown was measured manually by volumetric timing using a watch and a bucket of known volume by NPS personnel with the pump on, and water-level recovery was measured with the pump turned off. Water levels deeper than about $250 \mathrm{ft}$ could not be measured during the 2009 NPS test because pumping equipment in the well prevented the electric tape from reaching the water level.

The NPS single-well aquifer test in 2009 used a pumping rate of about $20 \mathrm{gal} / \mathrm{min}$. The well was pumped for $194 \mathrm{~min}-$ utes (3.2 hours) before pumping was discontinued. Water levels were measured with an electric tape at intervals ranging from 3 to 10 minutes with the pump on and 1 to 10 minutes with the pump off. Water-level measurements were recorded until the water level declined to about $150 \mathrm{ft}$ below the land surface. Water-level recovery was measured for about 148 minutes (2.5 hours) until water levels were within $40 \mathrm{ft}$ of the initial water level. Data recorded during the test included 71 observations of time and water-level displacement, measured in feet (table 3).

The USGS completed a single-well aquifer test at the Burnpit well (well 5; fig. 4) on June 24, 2020, in conjunction with the collection of water-quality samples. After about 10 years of nonuse, the original pump failed and was replaced with a temporary pump. The drilling contractor temporarily installed a Grundfos 16S30-24 pump at about $500 \mathrm{ft}$ below land surface. Additionally, a 1-in.-diameter black polyvinyl monitor tube was taped to the downpipe to facilitate waterlevel measurements during the test. Water levels were measured manually by USGS personnel using a 1,000-ft calibrated electric tape with a measuring point of $2.70 \mathrm{ft}$ above land surface established at the top of the monitor tube. Water discharged during pumping was routed through a 5-ft-long steel pipe attached to the well outlet and then downhill to a natural drainage. Infiltration of pumped water discharged at the surface was assumed to be minimal and to not affect the test; however, pooled water about $10 \mathrm{ft}$ south of the well infiltrated the land surface about 5 minutes after the pump was turned off. Weather was consistent during the test and did not affect test results. The weather was hot (as much as 80 degrees Fahrenheit) with light wind and no clouds, and the barometric pressure ranged from 634 to 635 millimeters of mercury during the test.
The USGS single-well aquifer test in 2020 used a pumping rate of about $27 \mathrm{gal} / \mathrm{min}$, which was the maximum capability of the pump and generator. The discharge rate from pumping was measured by recording the time with a stopwatch to fill a 5 -gal bucket. Discharge was measured five times during the pumping part of the test (table 3 ). Water-level measurements were recorded at intervals ranging from 1 to 13 minutes with the pump on and 15 seconds to 20 minutes with the pump off. More frequent measurements were made when the water-level changes were rapid, and less frequent measurements were made during slower water-level changes. The well was pumped for 186 minutes (3.1 hours), which was the time required to purge the well for water-quality sampling. The pump was turned off and water-level measurements were recorded for 195 minutes as the water level recovered. The test included 82 observations of time and water-level displacement, measured in feet (table 3).

AQTESOLV Pro version 4.50.002 (Hydrosolve, Inc., 2007) software was used to analyze data collected from the NPS and USGS single-well aquifer tests. The AQTESOLV software uses curve fitting of time and water-level data to estimate transmissivity and storage properties. The curve-fitting algorithm creates a best-fit curve by varying the estimated transmissivity and other hydraulic parameters until a theoretical curve best fits the measured time and water-level observations (Hydrosolve, Inc., 2007). Although AQTESOLV has an automatic curve-fitting feature, manual curve fitting was used for optimizing fit.

The Theis (Theis, 1935) and Cooper-Jacob (Cooper and Jacob, 1946) curve-matching techniques were used to determine aquifer transmissivity and storativity. The Theis method uses theoretical drawdown curves based on assumptions about the aquifer including an infinite areal extent, homogeneous and isotropic geologic material with uniform aquifer thickness, unconfined groundwater conditions, unsteady groundwater flow, fully or partially penetrating pumping well, and the displacement of water levels is small relative to saturated thickness (Hydrosolve, Inc., 2007). The Theis method was modified for use with data from an unconfined aquifer by correcting the drawdown data to account for aquifer saturated thickness (Kruseman and de Ridder, 1994; Hydrosolve, Inc., 2007). An advantage of the Theis method is that it considers drawdown and recovery water-level data when estimating aquifer hydrogeologic properties.

The Cooper-Jacob method (Cooper and Jacob, 1946) for an unconfined aquifer also was used to analyze the drawdown water-level data from the aquifer tests. Like the Theis method modification for unconfined aquifers, the Cooper-Jacob method adjusts water-level displacement data recorded during an aquifer test of an unconfined aquifer by considering the saturated thickness of the aquifer (Hydrosolve, Inc., 2007). The Cooper-Jacob method often is used for fractured rock aquifers to determine if wellbore water storage and geologic fractures change the slope of the time-drawdown water-level curves (Hydrosolve, Inc., 2007). Straight-line curve matching to the water-level drawdown data was used for the Cooper-Jacob 
Table 3. Water-level and time data recorded during Burnpit well (well 5) aquifer tests on August 25, 2009, by the National Park Service and on June 24, 2020, by the U.S. Geological Survey (Eldridge and Hoogestraat, 2021).

[NPS, National Park Service; USGS, U.S. Geological Survey; gal/min, gallon per minute; ft, foot; --, not applicable]

\begin{tabular}{|c|c|c|c|c|c|c|c|c|c|c|c|c|}
\hline \multicolumn{6}{|c|}{ NPS 2009 aquifer test ${ }^{1}$} & \multicolumn{7}{|c|}{ USGS 2020 aquifer test } \\
\hline \multicolumn{3}{|c|}{ Pump on at about $20 \mathrm{gal} / \mathrm{min}$} & \multicolumn{3}{|c|}{ Pump off } & \multicolumn{4}{|c|}{ Pump on at about $27 \mathrm{gal} / \mathrm{min}$} & \multicolumn{3}{|c|}{ Pump off } \\
\hline $\begin{array}{l}\text { Time from } \\
\text { test start } \\
\text { (minutes) }\end{array}$ & $\begin{array}{l}\text { Water-level } \\
\text { depth (ft } \\
\text { below land } \\
\text { surface) }\end{array}$ & $\begin{array}{l}\text { Water-level } \\
\text { displacement } \\
\text { from test start } \\
\text { (ft) }\end{array}$ & $\begin{array}{l}\text { Time from } \\
\text { test start } \\
\text { (minutes) }\end{array}$ & $\begin{array}{l}\text { Water-level } \\
\text { depth (ft } \\
\text { below land } \\
\text { surface) }\end{array}$ & $\begin{array}{l}\text { Water-level } \\
\text { displacement } \\
\text { from test } \\
\text { start (ft) }\end{array}$ & $\begin{array}{l}\text { Time from } \\
\text { test start } \\
\text { (minutes) }\end{array}$ & $\begin{array}{l}\text { Water-level } \\
\text { depth (ft } \\
\text { below land } \\
\text { surface) }\end{array}$ & $\begin{array}{c}\text { Water-level } \\
\text { displacement } \\
\text { from test start } \\
\text { (ft) }\end{array}$ & $\begin{array}{c}\text { Pump } \\
\text { discharge } \\
\text { (gal/min) }\end{array}$ & $\begin{array}{l}\text { Time from } \\
\text { test start } \\
\text { (minutes) }\end{array}$ & $\begin{array}{l}\text { Water-level } \\
\text { depth (ft } \\
\text { below land } \\
\text { surface) }\end{array}$ & $\begin{array}{l}\text { Water-level } \\
\text { displacement } \\
\text { from test start } \\
\text { (ft) }\end{array}$ \\
\hline 0 & 27.89 & 0.00 & 196 & 142.10 & 114.21 & 0 & 5.87 & 0 & -- & 188 & 193.40 & 187.53 \\
\hline 8 & 96.30 & 68.41 & 197 & 136.30 & 108.41 & 4 & 32.40 & 26.53 & 27 & 188.50 & 186.80 & 180.93 \\
\hline 11 & 93.20 & 65.31 & 198 & 132.30 & 104.41 & 5 & 44.20 & 38.33 & -- & 188.75 & 182.80 & 176.93 \\
\hline 15 & 93.85 & 65.96 & 199 & 128.40 & 100.51 & 7 & 59.80 & 53.93 & -- & 189.33 & 176.80 & 170.93 \\
\hline 20 & 96.35 & 68.46 & 200 & 125.25 & 97.36 & 9 & 70.90 & 65.03 & -- & 189.67 & 171.80 & 165.93 \\
\hline 25 & 99.40 & 71.51 & 201 & 122.70 & 94.81 & 11 & 81.20 & 75.33 & 27 & 190 & 165.80 & 159.93 \\
\hline 30 & 102.40 & 74.51 & 202 & 120.40 & 92.51 & 14 & 94.10 & 88.23 & -- & 191 & 161.80 & 155.93 \\
\hline 35 & 105.25 & 77.36 & 203 & 118.25 & 90.36 & 16 & 100.70 & 94.83 & -- & 192 & 154.80 & 148.93 \\
\hline 40 & 108.05 & 80.16 & 204 & 116.32 & 88.43 & 20 & 114.00 & 108.13 & -- & 194 & 147.80 & 141.93 \\
\hline 45 & 110.39 & 82.50 & 205 & 114.41 & 86.52 & 24 & 121.00 & 115.13 & -- & 196 & 141.80 & 135.93 \\
\hline 50 & 112.78 & 84.89 & 206 & 112.72 & 84.83 & 27 & 119.30 & 113.43 & -- & 198 & 137.80 & 131.93 \\
\hline 55 & 114.70 & 86.81 & 207 & 111.10 & 83.21 & 32 & 121.50 & 115.63 & -- & 200 & 133.80 & 127.93 \\
\hline 60 & 117.05 & 89.16 & 208 & 109.62 & 81.73 & 36 & 124.25 & 118.38 & -- & 202 & 129.70 & 123.83 \\
\hline 65 & 119.00 & 91.11 & 209 & 108.33 & 80.44 & 40 & 127.95 & 122.08 & -- & 204 & 126.20 & 120.33 \\
\hline 70 & 120.88 & 92.99 & 210 & 107.15 & 79.26 & 44 & 131.40 & 125.53 & 27 & 206 & 123.80 & 117.93 \\
\hline 75 & 122.67 & 94.78 & 211 & 105.91 & 78.02 & 49 & 135.70 & 129.83 & -- & 208 & 121.40 & 115.53 \\
\hline 80 & 124.40 & 96.51 & 212 & 104.81 & 76.92 & 54 & 139.75 & 133.88 & -- & 210 & 120.00 & 114.13 \\
\hline 85 & 126.02 & 98.13 & 213 & 103.81 & 75.92 & 60 & 144.50 & 138.63 & -- & 212 & 118.40 & 112.53 \\
\hline 90 & 127.60 & 99.71 & 214 & 102.85 & 74.96 & 65 & 147.85 & 141.98 & -- & 214 & 116.35 & 110.48 \\
\hline 95 & 129.12 & 101.23 & 215 & 101.95 & 74.06 & 70 & 151.65 & 145.78 & -- & 216 & 116.00 & 110.13 \\
\hline 100 & 130.60 & 102.71 & 218 & 99.55 & 71.66 & 76 & 155.10 & 149.23 & -- & 218 & 113.50 & 107.63 \\
\hline 105 & 132.05 & 104.16 & 220 & 98.10 & 70.21 & 81 & 158.23 & 152.36 & -- & 220 & 111.50 & 105.63 \\
\hline 115 & 134.80 & 106.91 & 225 & 94.98 & 67.09 & 86 & 160.90 & 155.03 & -- & 223 & 109.92 & 104.05 \\
\hline 125 & 137.30 & 109.41 & 230 & 92.31 & 64.42 & 92 & 164.50 & 158.63 & -- & 226 & 108.10 & 102.23 \\
\hline 135 & 139.68 & 111.79 & 235 & 89.95 & 62.06 & 97 & 167.22 & 161.35 & -- & 228 & 106.77 & 100.90 \\
\hline 145 & 141.95 & 114.06 & 240 & 87.90 & 60.01 & 103 & 170.75 & 164.88 & -- & 230 & 105.62 & 99.75 \\
\hline 155 & 144.12 & 116.23 & 245 & 86.01 & 58.12 & 110 & 173.83 & 167.96 & -- & 235 & 103.13 & 97.26 \\
\hline
\end{tabular}


Table 3. Water-level and time data recorded during Burnpit well (well 5) aquifer tests on August 25, 2009, by the National Park Service and on June 24, 2020, by the

[NPS, National Park Service; USGS, U.S. Geological Survey; gal/min, gallon per minute; ft, foot; --, not applicable]

\begin{tabular}{|c|c|c|c|c|c|c|c|c|c|c|c|c|}
\hline \multicolumn{6}{|c|}{ NPS 2009 aquifer test ${ }^{1}$} & \multicolumn{7}{|c|}{ USGS 2020 aquifer test } \\
\hline \multicolumn{3}{|c|}{ Pump on at about $20 \mathrm{gal} / \mathrm{min}$} & \multicolumn{3}{|c|}{ Pump off } & \multicolumn{4}{|c|}{ Pump on at about $27 \mathrm{gal} / \mathrm{min}$} & \multicolumn{3}{|c|}{ Pump off } \\
\hline $\begin{array}{l}\text { Time from } \\
\text { test start } \\
\text { (minutes) }\end{array}$ & $\begin{array}{c}\text { Water-level } \\
\text { depth (ft } \\
\text { below land } \\
\text { surface) }\end{array}$ & $\begin{array}{l}\text { Water-level } \\
\text { displacement } \\
\text { from test start } \\
\text { (ft) }\end{array}$ & $\begin{array}{l}\text { Time from } \\
\text { test start } \\
\text { (minutes) }\end{array}$ & $\begin{array}{l}\text { Water-level } \\
\text { depth (ft } \\
\text { below land } \\
\text { surface) }\end{array}$ & $\begin{array}{l}\text { Water-level } \\
\text { displacement } \\
\text { from test } \\
\text { start (ft) }\end{array}$ & $\begin{array}{l}\text { Time from } \\
\text { test start } \\
\text { (minutes) }\end{array}$ & $\begin{array}{l}\text { Water-level } \\
\text { depth (ft } \\
\text { below land } \\
\text { surface) }\end{array}$ & $\begin{array}{l}\text { Water-level } \\
\text { displacement } \\
\text { from test start } \\
\text { (ft) }\end{array}$ & $\begin{array}{c}\text { Pump } \\
\text { discharge } \\
\text { (gal/min) }\end{array}$ & $\begin{array}{l}\text { Time from } \\
\text { test start } \\
\text { (minutes) }\end{array}$ & $\begin{array}{l}\text { Water-level } \\
\text { depth (ft } \\
\text { below land } \\
\text { surface) }\end{array}$ & $\begin{array}{l}\text { Water-level } \\
\text { displacement } \\
\text { from test star } \\
\text { (ft) }\end{array}$ \\
\hline 165 & 146.22 & 118.33 & 250 & 84.35 & 56.46 & 115 & 176.63 & 170.76 & -- & 238 & 101.82 & 95.95 \\
\hline 175 & 148.21 & 120.32 & 255 & 82.82 & 54.93 & 122 & 179.52 & 173.65 & -- & 245 & 98.75 & 92.88 \\
\hline 185 & 150.16 & 122.27 & 260 & 81.45 & 53.56 & 128 & 181.78 & 175.91 & 26 & 251 & 96.40 & 90.53 \\
\hline 194 & 151.80 & 123.91 & 265 & 80.15 & 52.26 & 133 & 184.09 & 178.22 & -- & 261 & 93.45 & 87.58 \\
\hline-- & -- & -- & 270 & 78.92 & 51.03 & 138 & 185.99 & 180.12 & -- & 271 & 90.18 & 84.31 \\
\hline -- & -- & -- & 275 & 78.01 & 50.12 & 144 & 187.98 & 182.11 & -- & 281 & 87.20 & 81.33 \\
\hline -- & -- & -- & 285 & 75.70 & 47.81 & 149 & 189.86 & 183.99 & -- & 291 & 85.00 & 79.13 \\
\hline-- & -- & -- & 295 & 73.85 & 45.96 & 153 & 191.33 & 185.46 & -- & 301 & 82.70 & 76.83 \\
\hline -- & -- & -- & 305 & 72.15 & 44.26 & 159 & 193.15 & 187.28 & -- & 311 & 80.48 & 74.61 \\
\hline-- & -- & -- & 315 & 70.58 & 42.69 & 163 & 194.65 & 188.78 & -- & 321 & 78.53 & 72.66 \\
\hline -- & -- & -- & 325 & 69.13 & 41.24 & 169 & 196.60 & 190.73 & -- & 341 & 74.78 & 68.91 \\
\hline-- & -- & -- & 335 & 67.80 & 39.91 & 182 & 200.73 & 194.86 & 26 & 351 & 73.00 & 67.13 \\
\hline-- & -- & -- & 344 & 66.65 & 38.76 & 186 & 202.12 & 196.25 & -- & 361 & 71.43 & 65.56 \\
\hline -- & -- & -- & -- & -- & -- & -- & -- & -- & -- & 371 & 70.10 & 64.23 \\
\hline -- & -- & -- & -- & -- & -- & -- & -- & -- & -- & 381 & 68.66 & 62.79 \\
\hline
\end{tabular}

${ }^{1}$ Pump discharge records for the 2009 NPS aquifer test were not available, and only the mean rate was recorded (Larry Martin, National Park Service, written commun., 2009). 


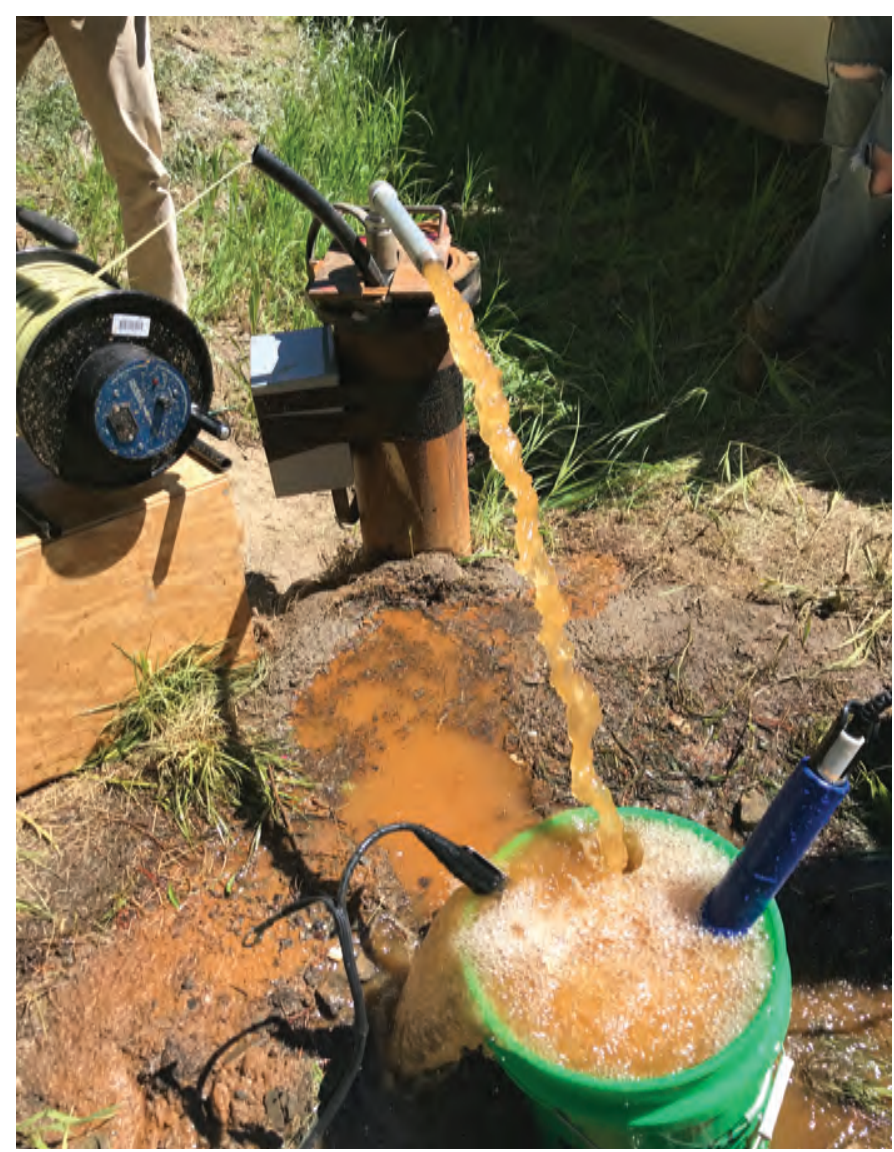

Figure 4. The Burnpit well (well 5) during aquifer testing on June 24, 2020, at Mount Rushmore National Memorial.

method, which differs from the multiple curve-matching method used by the Theis method that matches drawdown and recovery data. Several solutions for fractured aquifers are available in AQTESOLV but were not used for this study because the solutions are optimized for aquifer tests with data from a pumping well and observation wells, and the solutions require the geometry of the fractures and rock slabs (Moench, 1984; Barker, 1988); neither were available or known for the NPS and USGS aquifer tests.

The data needed for curve-matching analyses in AQTESOLV included well construction information, water-level drawdown data, and water-level recovery data. Well construction information was obtained from the well logs and field measurements (table 4). Well depth was reported as $580 \mathrm{ft}$ with $42 \mathrm{ft}$ of 8-in.-diameter (0.33-ft-radius) steel casing installed in the 10-in. well boring from 0 to $40 \mathrm{ft}$ below land surface. The well casing extends about $2 \mathrm{ft}$ above the land surface. The remaining $540 \mathrm{ft}$ of well depth is open hole with a 6-in. diameter ( $0.25-\mathrm{ft}$ radius) from 40 to $580 \mathrm{ft}$ below land surface. Aquifer saturated thickness, which is based on the water level at the start of the aquifer test, was measured as 552 and $574 \mathrm{ft}$ for the NPS (2009) and USGS (2020) tests, respectively, and the aquifer hydraulic conductivity anisotropy ratio was estimated as 0.1 (based on shale; Hydrosolve, Inc., 2007).
The well does not have a well skin because it is largely open hole and in direct contact with the aquifer. Downhole equipment and well packers were not used for either test. The well was defined as a partially penetrating well in an unconfined aquifer for AQTESOLV analysis because the open hole interval of the well does not extend over the full aquifer thickness. The depth to the top of the open interval from the water table was 12 and $34 \mathrm{ft}$ for the NPS and USGS aquifer tests, respectively, and the open interval length was $540 \mathrm{ft}$ (table 4).

Water-level and time data collected during the NPS and USGS aquifer tests (table 3 ) were converted to displacement water levels for use with AQTESOLV. Water-level data were converted to water-level displacement by subtracting a datum water level measured before the aquifer test (static water level) from the water-level measurements recorded during and after pumping; therefore, the starting water-level displacement was zero, and subsequent water-level displacements were the difference from the starting water level. Time was recorded in minutes from the start of the test. Time and water-level displacement curves were plotted for the NPS and USGS aquifer tests (fig. 5).

\section{Water Quality}

Water-quality samples were collected in June and July 2020 at the Burnpit well and analyzed for 36 constituents. Field water-quality properties including dissolved oxygen, $\mathrm{pH}$, specific conductance, water temperature, and turbidity also were measured with a multiparameter sonde (Xylem EXO1). Field water-quality properties were measured about every 15 minutes while the Burnpit well was pumped for about 3 hours to purge three well volumes (about 5,000 gal) of water before collecting water-quality samples. Physical properties are critical in understanding the viability and vulnerability of environmental waters and are considered important variables in determining the aqueous chemistry of a groundwater system. Groundwater-level fluctuations from aquifer storage changes involve either the addition or extraction of water from the aquifer through natural and human processes and can cause variation in field properties. Potential sources for major ions or trace elements in water resources within the memorial include the dissolution of minerals that constitute granite and schists in contact with groundwater in the study area or other human factors related to construction, infrastructure, and vehicle traffic.

Groundwater samples were collected and field measurements were made using procedures described in U.S. Geological Survey (variously dated). Groundwater samples were analyzed for selected trace metals using inductively coupled plasma mass spectrometry by the USGS National Water Quality Laboratory in Lakewood, Colorado, using methods described in Garbarino and Struzeski (1998); major ions were analyzed using inductively coupled plasma atomic emission spectrophotometry (Fishman, 1993) or ion chromatography (Fishman and Friedman, 1989); nutrients 
Table 4. Input parameter values for the Burnpit well (well 5) and aquifer characteristics used by AOTESOLV (Hydrosolve, Inc., 2007) to estimate transmissivity and storage parameters from aquifer-test data collected August 25, 2009, and June 24, 2020, at Mount Rushmore National Memorial.

[NPS, National Park Service; --, not applicable; ft, foot; USGS, U.S. Geological Survey; Kv, vertical hydraulic conductivity; Kh, horizontal hydraulic conductivity]

\begin{tabular}{|c|c|c|c|}
\hline Parameter & Parameter symbol'; unit & Value & Notes and sources \\
\hline $\begin{array}{l}\text { Static water level before NPS test (below land } \\
\text { surface) }\end{array}$ & $--; \mathrm{ft}$ & 27.89 & Recorded by NPS, August 25, 2009. \\
\hline $\begin{array}{l}\text { Static water level before USGS test (below land } \\
\text { surface) }\end{array}$ & $--; \mathrm{ft}$ & 5.87 & Recorded by USGS, June 24, 2020. \\
\hline Well depth & $--; \mathrm{ft}$ & 580 & $\begin{array}{l}\text { Well log (South Dakota Department of Environment and Natural } \\
\text { Resources, 2020). }\end{array}$ \\
\hline Aquifer saturated thickness for NPS aquifer test & $\mathrm{b} ; \mathrm{ft}$ & 552 & $\begin{array}{l}\text { Well depth minus static water level recorded by the NPS before the } \\
\text { August 25, 2009, test. }\end{array}$ \\
\hline Aquifer saturated thickness for USGS aquifer test & $\mathrm{b} ; \mathrm{ft}$ & 574 & $\begin{array}{l}\text { Well depth minus static water level recorded by the USGS before the } \\
\text { June 24, 2020, test. }\end{array}$ \\
\hline Depth to top of open interval NPS test & $\mathrm{d} ; \mathrm{ft}$ & 12 & $\begin{array}{l}\text { The depth from the water table to the open hole for an unconfined } \\
\text { aquifer. }\end{array}$ \\
\hline Depth to top of open interval USGS test & $\mathrm{d} ; \mathrm{ft}$ & 34 & $\begin{array}{l}\text { The depth from the water table to the open hole for an unconfined } \\
\text { aquifer. }\end{array}$ \\
\hline Hydraulic conductivity anisotropy ratio & Kv/Kh (unitless ratio) & 0.1 & Hydrosolve, Inc. (2007) \\
\hline Open interval length & $\mathrm{L} ; \mathrm{ft}$ & 540 & $\begin{array}{l}\text { The length of the saturated screen or open hole for an unconfined } \\
\text { aquifer (the part of the well screen above the water table is ig- } \\
\text { nored). }\end{array}$ \\
\hline Inside radius of well casing & $\mathrm{r}(\mathrm{c}) ; \mathrm{ft}$ & 0.33 & Field measured inside radius of large casing. \\
\hline Radius of well (open or perforated interval) & $\mathrm{r}(\mathrm{w}) ; \mathrm{ft}$ & 0.25 & $\begin{array}{l}\text { Well log, open hole radius (South Dakota Department of } \\
\text { Environment and Natural Resources, 2020). }\end{array}$ \\
\hline Radius of downhole equipment & $\mathrm{r}(\mathrm{eq}) ; \mathrm{ft}$ & 0 & None, no downhole equipment was used for testing. \\
\hline Inside radius of packer & $\mathrm{r}(\mathrm{p}) ; \mathrm{ft}$ & 0 & None, packers were not used for testing. \\
\hline Outer radius of well skin & $\mathrm{r}(\mathrm{sk}) ; \mathrm{ft}$ & 0 & None, well is largely open hole and in direct contact with the aquifer. \\
\hline
\end{tabular}

1Parameter symbols used in AQTESOLV software (Hydrosolve, Inc., 2007). 


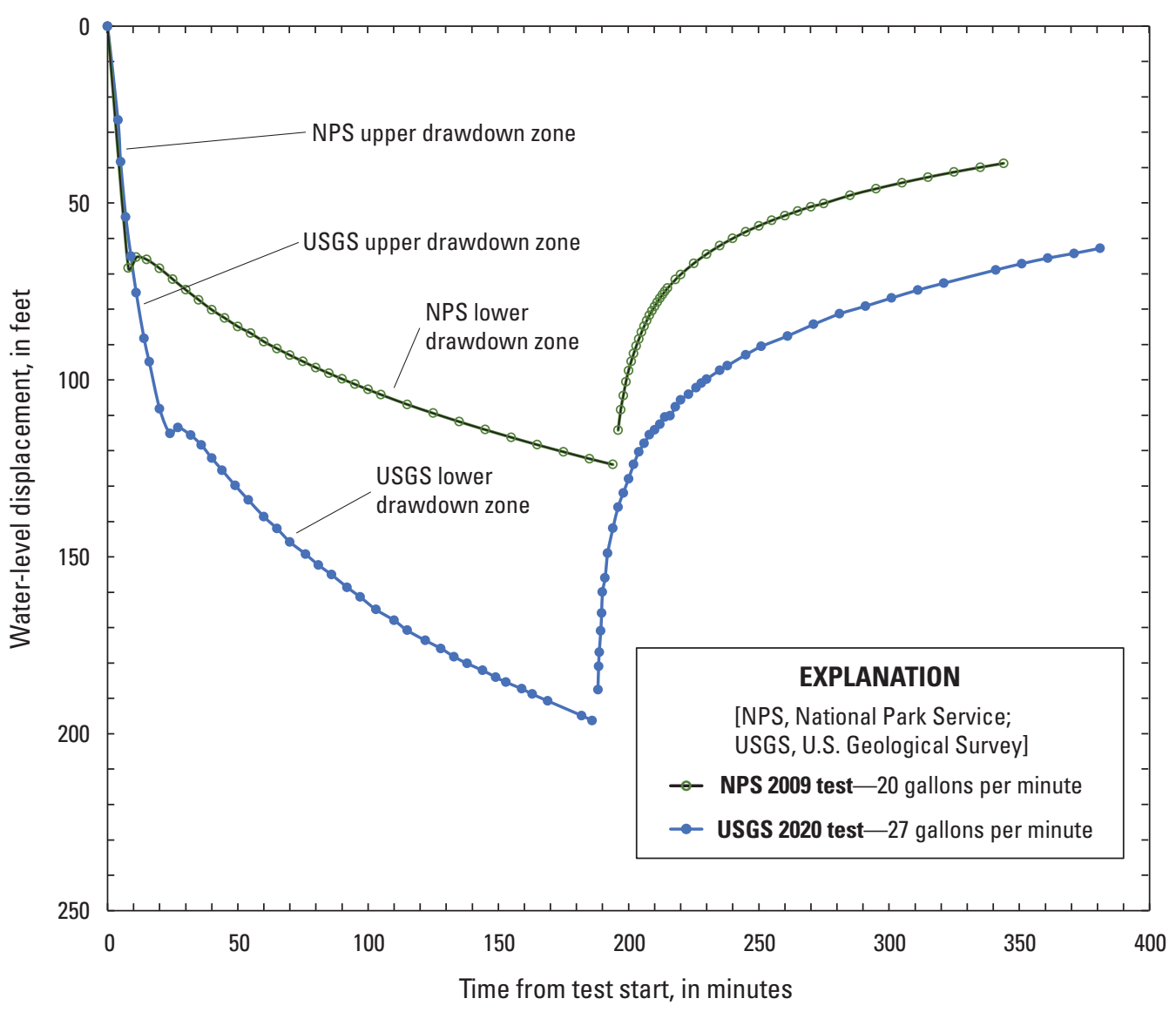

Figure 5. Time and water-level displacement curves for the National Park Service 2009 and the U.S. Geological Survey 2020 aquifer tests of the Burnpit well, Mount Rushmore National Memorial. were analyzed using colorimetric determination (Fishman, 1993; Patton and Kryskalla, 2011); perchlorate was analyzed using U.S. Environmental Protection Agency (EPA) method 6860 by SGS Laboratories (Orlando, Florida) using ion chromatography/electrospray ionization/mass spectrometry (U.S. Environmental Protection Agency, 2007).

\section{Borehole Analysis, Single-Well Aquifer Testing, and Water Quality}

Results from borehole analyses, single-well aquifer testing, and water-quality sampling provided information on aquifer properties and water chemistry for the Burnpit well. Borehole camera video and aquifer-test data collected during this study are available in a USGS data release (Eldridge and Hoogestraat, 2021) and summarized in this report, and water-quality data are available from the USGS National Water Information System (USGS site 435240103265301; U.S. Geological Survey, 2021).

\section{Borehole Analysis}

Borehole analyses included results from lithologic information in the well log and from borehole camera video. Fractures in the well lithologic log correlated with fractures observed in the borehole camera video; however, not all fractures observed in the borehole camera video were documented in the well log.

The well log for the Burnpit well included a lithologic log of the geologic material near the well and well construction information (South Dakota Department of Environment and Natural Resources, 2020). The well log recorded a well depth of $580 \mathrm{ft}$ below land surface with the upper $42 \mathrm{ft}$ of the well (including $2 \mathrm{ft}$ of well casing above the land surface) cased with 8-in. schedule 40 steel and the lower $540 \mathrm{ft}$ of the well as open hole with a diameter of 6 in. The casing was grouted with a Type II Portland cement grout with 8-percent bentonite clay to a depth of $40 \mathrm{ft}$ below land surface. The lithologic log recorded schist and pegmatite formations with prominent quartz veins, as well as six zones between fractures ranging in thickness between 1 and $10 \mathrm{ft}$ (table 5). Hard schists were recorded for the first $80 \mathrm{ft}$ of the well depth, likely corresponding to the schist, quartzite, and metaconglomerate geologic unit mapped in the area of the Burnpit well (well 5; fig. 3). 
Table 5. Lithologic descriptions of geologic formations of the Burnpit well (well 5) from the driller well log with depth to the top and bottom of the units from land surface, unit thicknesses, and estimated pumping rate (South Dakota Department of Environment and Natural Resources, 2020).

[gal/min, gallon per minute; --, not applicable]

\begin{tabular}{|c|c|c|c|}
\hline Lithologic description ${ }^{1}$ & $\begin{array}{l}\text { Depth to top and bottom of unit from } \\
\text { land surface (feet) }\end{array}$ & Unit thickness (feet) & $\begin{array}{c}\text { Estimated aquifer production } \\
\text { rate (gal } / \mathrm{min})\end{array}$ \\
\hline Schist, medium hard & $0-45$ & 45 & -- \\
\hline Schist, gray hard & $45-80$ & 35 & -- \\
\hline Quartz & $80-120$ & 40 & -- \\
\hline Fracture, trace water & $120-121$ & 1 & Trace \\
\hline Schist, gray hard & $121-145$ & 24 & -- \\
\hline Pegmatite, some mica & $145-200$ & 55 & -- \\
\hline Quartz & $200-220$ & 20 & -- \\
\hline Schist, gray medium hard & $220-250$ & 30 & -- \\
\hline Quartz & $250-275$ & 25 & -- \\
\hline Quartz fracture & $275-276$ & 1 & 3 \\
\hline Schist, some quartz & $276-310$ & 34 & -- \\
\hline Schist fracture & $310-312$ & 2 & 10 \\
\hline Quartz & $312-340$ & 28 & -- \\
\hline Schist, gray & $340-410$ & 70 & -- \\
\hline Schist fracture & $410-420$ & 10 & 15 \\
\hline Schist, gray hard & $420-460$ & 40 & -- \\
\hline Quartz fracture & $460-462$ & 2 & 20 \\
\hline Quartz & $462-480$ & 18 & -- \\
\hline Quartz fracture & $480-485$ & 5 & 35 \\
\hline Schist, gray hard & $485-580$ & 95 & -- \\
\hline
\end{tabular}

${ }^{1}$ Lithologic description is from the driller's well log and may be generalized.

Quartz veins were noted four times in the lithologic log and are common geologic features in the area near the Burnpit well. Dikes and sills containing quartz were recorded in lithologic logs of other wells at the memorial (Powell and others, 1973), and quartz veins were noted on geologic maps of the memorial (fig. 3).

Fractures in quartz and schist formations were recorded six times in the lithologic log at $120,275,310,410,460$, and $480 \mathrm{ft}$ below land surface. The fracture at a depth of $120 \mathrm{ft}$ below land surface was noted to include trace water. Estimated aquifer production rates of $3,10,15,20$, and $35 \mathrm{gal} / \mathrm{min}$ were noted for the fractures at 275, 310, 410, 460, and $480 \mathrm{ft}$ below land surface, respectively (table 5 ). The well log also recorded that after hydraulic fracturing, the well produced $55 \mathrm{gal} / \mathrm{min}$; however, the methods used during fracturing, such as wellpacker depths and pressures, were not recorded. Hydraulic fracturing possibly enhanced groundwater flow to the well by creating new flow paths or by increasing the size and connectivity of preexisting fractures.
Borehole camera video from June 23 recorded the water level at about $4 \mathrm{ft}$ below land surface. The depth to the bottom of the steel casing was not observed in the June 23 borehole camera video because sediments clouded the video images of the casing. Borehole camera video from July 29 recorded the water level at about $22.5 \mathrm{ft}$ below land surface and the bottom of the steel casing at about $38 \mathrm{ft}$ below land surface.

Images from the June 23 and July 29 borehole camera videos showed anthropogenic debris and sediments in the well. Anthropogenic debris, likely plastic straps, tape, or zip ties were observed at depths of 121, 202, 224, 258, and $492 \mathrm{ft}$ below land surface. The June 23 and the July 29 videos recorded suspended sediments and particles of undetermined size in the groundwater throughout the recorded length of the borehole. The June 23 video showed a higher concentration of sediments than the July 29 video. The difference in sediment density between the two videos likely was because the well was purged for water-quality sampling on June 24 and July 23 and about 5,000 gal of water were pumped from the well before each water-quality sample. Well purging on these two 
dates was after the June 23 recording but before the July 29 recording. Purging likely removed accumulated sediments from the well, resulting in a clearer video recorded on July 29. A few quartz veins were observed in the videos but were difficult to discern because of the rate that the camera was lowered in the borehole and the presence of debris and sediments. Quartz veins were observed in the video from 85 to $87.5 \mathrm{ft}$ and from 95 to $100 \mathrm{ft}$. The depths of the quartz veins in the borehole camera video matched a quartz vein recorded in the well log from 80 to $120 \mathrm{ft}$ below land surface (table 5).
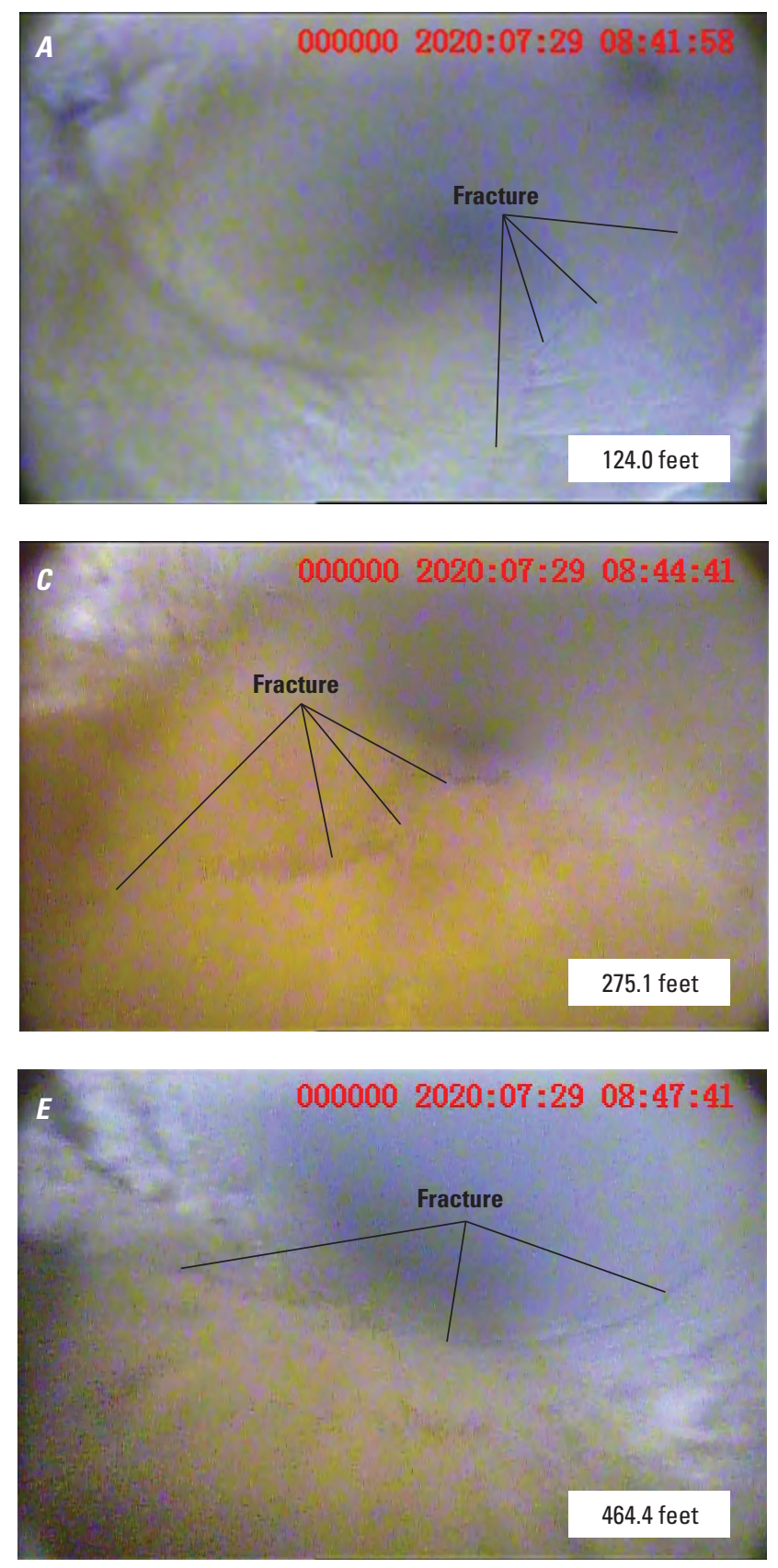

Geologic fractures also were observed in the June 24 and July 23 videos. Fractures were observed at about 124, 238, 275, 418, 464, and $482 \mathrm{ft}$ below land surface (fig. 6A-F). Fractures at approximately 124, 275, 418, 464, and $482 \mathrm{ft}$ (fig. $6 A, C, D, E$, and $F$, respectively) approximately correspond to fractures recorded in the well log for the Burnpit well (well 5; table 4) within the 2-ft accuracy for depth recorded by the video camera system. The fracture at 310-312 ft below land surface recorded in the well log was not observed in either video. Observed fractures were oriented vertically and
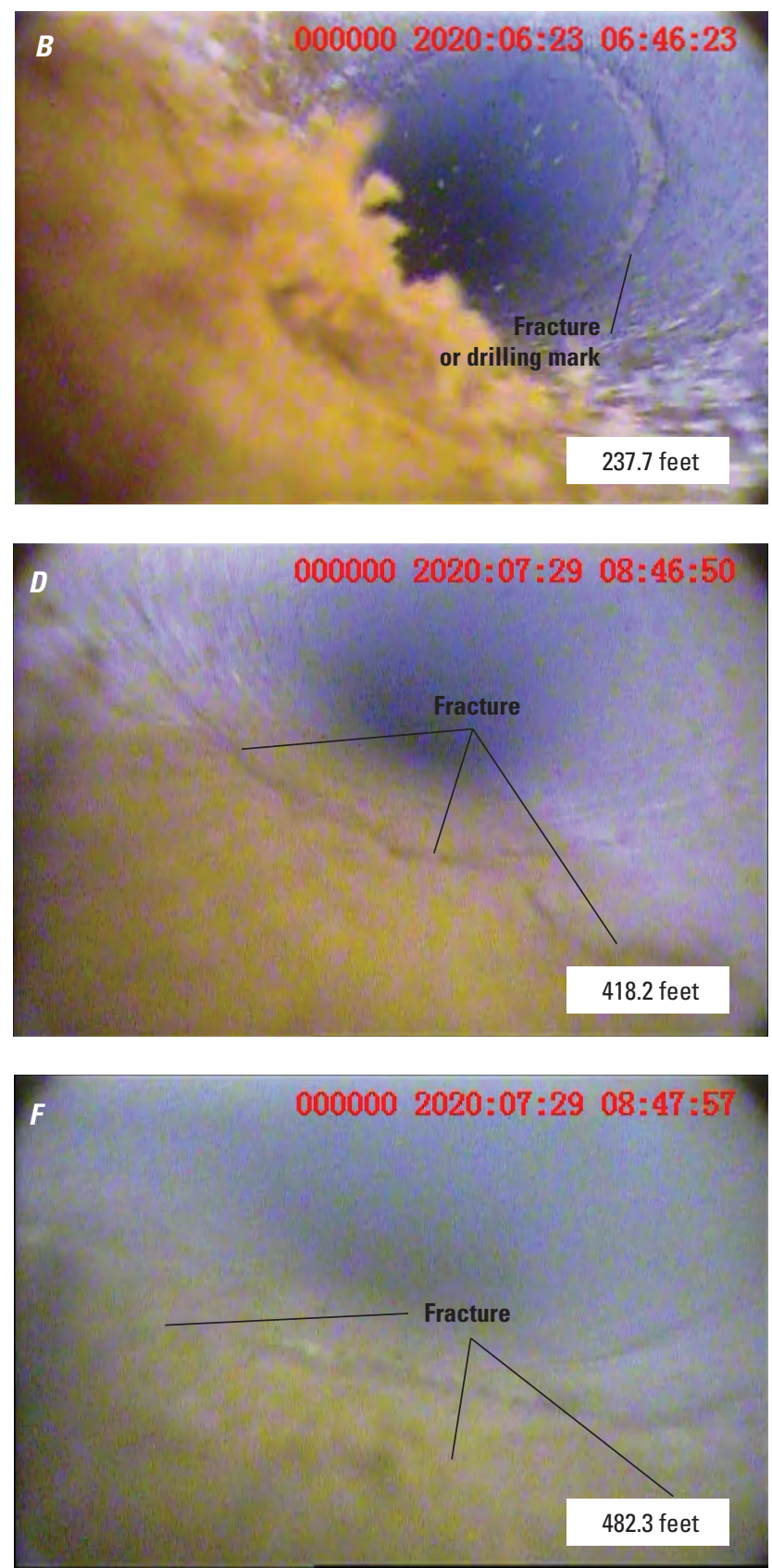

Figure 6. Images from borehole camera video recorded on June 23 and July 29 of the Burnpit well (well 5) at Mount Rushmore National Memorial by National Park Service personnel. $A$, fractures at 124.0 feet (ft); $B$, fracture at $237.7 \mathrm{ft}$; $C$, fractures at $275.1 \mathrm{ft}$; $D$, fractures at $418.2 \mathrm{ft}$; $E$, fractures at $464.4 \mathrm{ft}$; $F$, fractures at $482.3 \mathrm{ft}$. 
horizontally in the borehole (fig. $6 A, C, D, E$, and F). Video recordings of smaller fractures and sidewall roughness were observed at about 20 other depths in the borehole. Some borehole features that were assumed to be fractures may have been drill bit cuts or marks made during drilling operations; for example, figure $6 B$ shows a circular feature spanning the circumference of the borehole. The circular feature could be a fracture or a mark made by the drill bit or other drilling equipment.

Borehole camera video was useful for characterizing the aquifer providing groundwater to the Burnpit well, and camera video generally matched the lithology recorded in the well log. The aquifer providing groundwater to the Burnpit well contained many fractures oriented horizontally and vertically, and some were observed in camera videos for several feet in length along the borehole wall. Quartz veins in the schist also provide additional fractures accommodating groundwater flow. Fractures recorded in the well $\log$ and observed with the borehole camera, including more than 20 less prominent fractures and rough sidewall areas, indicated a fractured aquifer. The fractures are the primary conduits for groundwater flow through the rock into the Burnpit well.

\section{Single-Well Aquifer Testing}

Single-well aquifer-test data from the NPS and USGS aquifer tests were analyzed with AQTESOLV software (Hydrosolve, Inc., 2007) using manual curve-matching techniques; however, the rate of water-level drawdown during the NPS and USGS aquifer tests changed during the tests as indicated by slope changes observed in the drawdown curves (fig. 5). Therefore, curve matching was completed for parts of the curves corresponding to the upper and lower drawdown zones for the NPS and USGS aquifer tests.

The NPS and USGS tests recorded relatively rapid waterlevel drawdown from 0 to 8 and 0 to 24 minutes, respectively. The change in water-level drawdown rates for the upper and lower drawdown zones during the aquifer test also was observed when the water-level displacement was plotted with time on a logarithmic scale (figs. 7, 8). However, plots of the USGS aquifer test (fig. 8) showed a more pronounced difference between the upper and lower drawdown zones than plots of the NPS aquifer test (fig. 7).

Data from the upper and lower drawdown zones were analyzed separately in AQTESOLV for the NPS and USGS aquifer tests assuming that the hydraulic properties of the upper drawdown zone of the aquifer (about the upper $120 \mathrm{ft}$ of the aquifer) differed from the hydraulic properties of the lower drawdown zone. The Theis and the Cooper-Jacob methods were used to curve match the upper drawdown zone (figs. $7 \mathrm{~A}$ and $C, 8 A$ and $C$ ) and lower drawdown zone (figs. $7 B$ and $D$, $8 B$ and $D$ ) pumping time-displacement curves for the NPS and USGS tests. Transmissivity and storage were estimated from curve matching the upper and lower drawdown zones for both tests.

\section{Transmissivity Estimates}

Transmissivity is the capacity of an aquifer to convey water and is equal to the hydraulic conductivity of an aquifer multiplied by the saturated thickness (Heath, 1983). Transmissivity was estimated for the upper and lower drawdown zones at the Burnpit well using the Theis (Theis, 1935) and Cooper-Jacob (Cooper and Jacob, 1946) methods of curve fitting applied to time and water-level displacement data recorded during the NPS and USGS aquifer tests (table 6).

Transmissivity for the NPS test using the Theis method was 9.0 and 11 feet squared per day $\left(\mathrm{ft}^{2} / \mathrm{d}\right)$ for the upper and lower drawdown zones, respectively (fig. 7A, $B$ ). Using the Cooper-Jacob method, the transmissivity was 22 and $14 \mathrm{ft}^{2} / \mathrm{d}$ for the upper and lower drawdown zones of the aquifer, respectively (fig. 7C, D). Transmissivity estimates from the USGS aquifer-test data were similar to estimates from the NPS aquifer test (table 6). The Theis method, applied to the upper and lower drawdown zones of the aquifer, produced transmissivity estimates of 7.7 and $10 \mathrm{ft}^{2} / \mathrm{d}$, respectively (fig. $8 A, B$ ), and the Cooper-Jacob method produced estimates of 9.7 and $12 \mathrm{ft}^{2} / \mathrm{d}$, respectively (fig. $8 C, D$ ).

The transmissivity estimates for the upper and lower drawdown zones were similar between the NPS and USGS aquifer tests, but one discrepancy was observed. The transmissivity estimates of the upper drawdown zone were about $2 \mathrm{ft}^{2} / \mathrm{d}$ less than the lower drawdown zone, except for the discrepancy of the NPS aquifer test using the Cooper-Jacob method where the upper drawdown zone was $8 \mathrm{ft}^{2} / \mathrm{d}$ greater than the lower drawdown zone. The transmissivity differences in the NPS test using the Cooper-Jacob method likely were caused by curve-matching misfit from using manual curve matching. The upper drawdown zone in figure $7 C$ analyzed using the Cooper-Jacob method was difficult to curve match. Additionally, the upper drawdown zone data from the NPS test differed from the upper drawdown zone data from the USGS test (figs. $7 C$ and $8 C$ ), which had more easily observed differences between the upper and lower drawdown zones. Curve matching for the upper and lower drawdown zone time-displacement curves for the USGS test was easier than for the NPS test because the slope and curve changes observed during the USGS test were more pronounced than in the NPS test (figs. 7 and 8). The difficulty in curve matching the upper drawdown zone for the NPS test made the analysis and transmissivity results less certain than the USGS test. 



\section{EXPLANATION \\ - Curve-matched analytical solution \\ - Water-level observation}
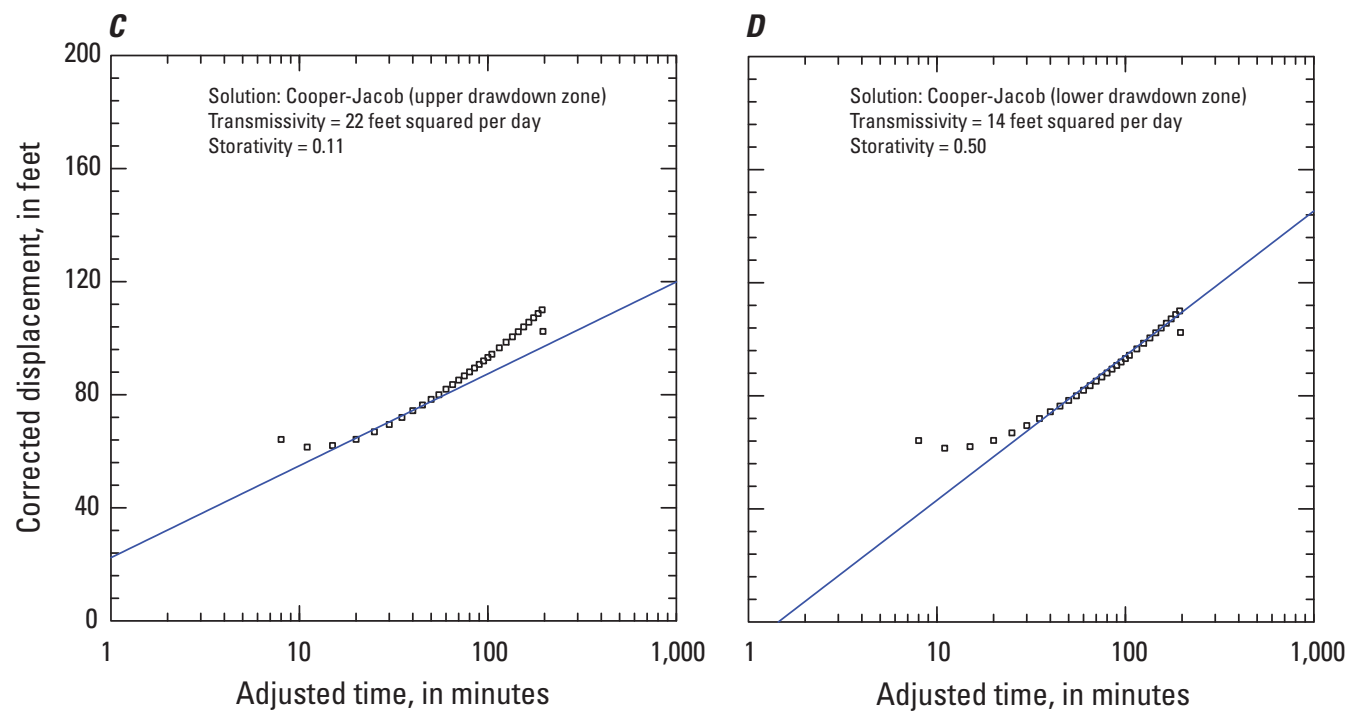

Figure 7. Water-level displacement (in feet) and time (in minutes) with analytical method and curve-matching results for the National Park Service aquifer test completed on August 25, 2009. $A$, for the Theis solution with upper drawdown zone data; $B$, for the Theis solution with lower drawdown zone data; $C$, for the Cooper-Jacob method with upper drawdown zone data; $D$, for the Cooper-Jacob method with lower drawdown zone data.

\section{Aquifer Storage Estimates}

Aquifer storage was estimated as storativity for the NPS and USGS aquifer tests (table 6). Storativity in an unconfined aquifer is nearly equal to specific yield (Hydrosolve, Inc., 2007). Specific yield is defined as the volume of water released from storage in an unconfined aquifer per unit surface area of the aquifer per unit decline of the water table (Hydrosolve, Inc., 2007). Specific yields for isotropic rock generally range from 0.1 for limestones to 0.3 for schists (Hydrosolve, Inc., 2007); however, fractures can increase the specific yield of rock by enhancing secondary permeability (Carter and others, 2002).
Storativity (specific yield) estimated using the Theis method for the NPS aquifer-test data was 0.85 and 0.92 for the upper and lower drawdown zones of the aquifer, respectively (fig. 7A, B). The Cooper-Jacob method applied to NPS aquifertest data produced storativity estimates of 0.11 and 0.50 for the upper and lower drawdown zones, respectively (fig. 7C, $D$ ). Storativity estimates from the USGS aquifer-test data were similar with the upper drawdown zone having a lower storativity than the lower drawdown zone. The Theis method applied to the USGS aquifer-test data estimated storativity values of 0.77 and 1.0 for the upper and lower drawdown zones, respectively (fig. 8A, $B$ ). The Cooper-Jacob method estimated storativity of 0.50 and 0.60 for the upper and lower drawdown zones of the USGS aquifer test, respectively (fig. $8 C, D$ ). 

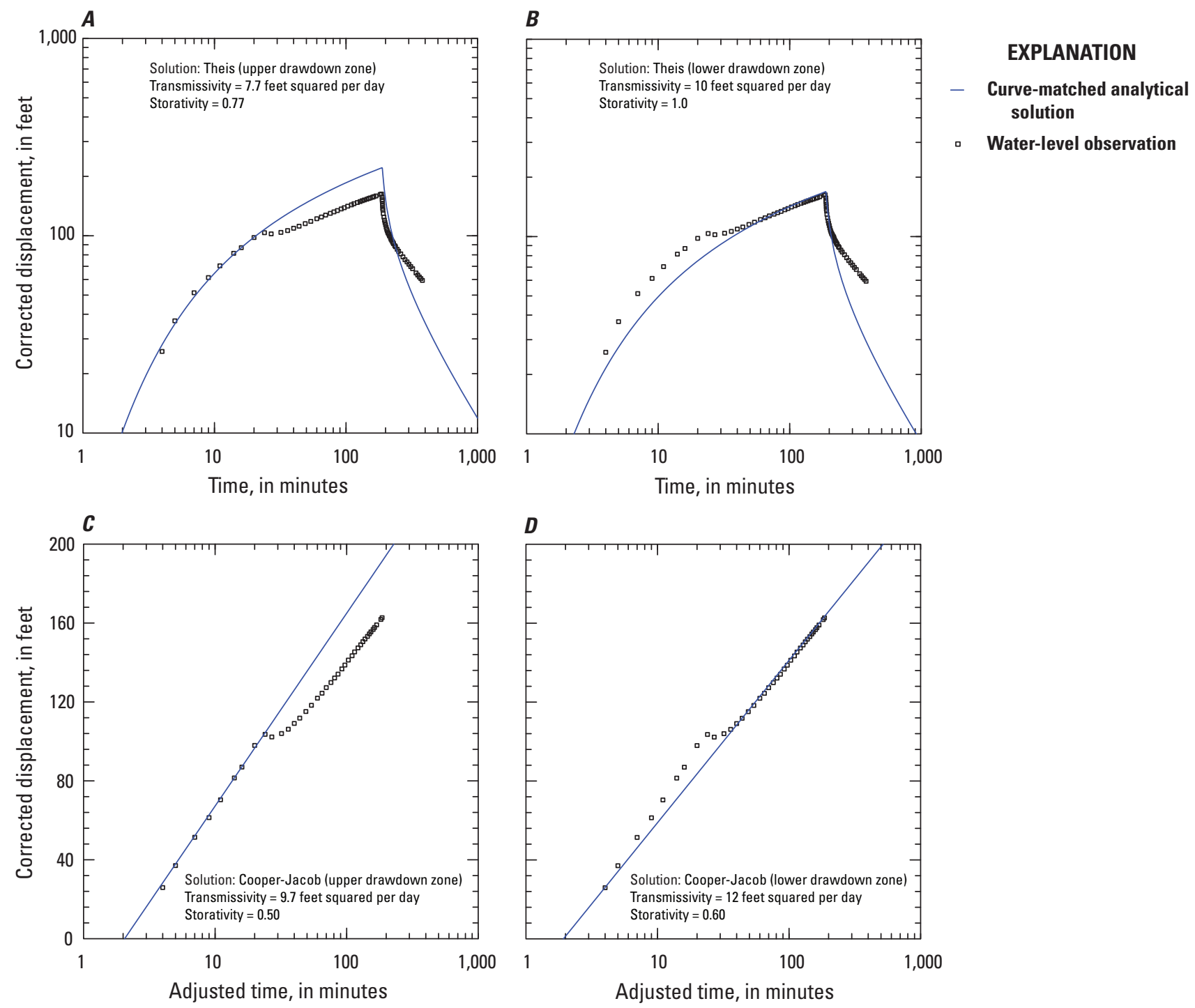

Figure 8. Water-level displacement (in feet) and time (in minutes) with analytical method and curve-matching results for the U.S. Geological Survey aquifer test completed on June 24,2020 . $A$, for the Theis solution with upper drawdown zone data; $B$, for the Theis solution with lower drawdown zone data; $C$, for the Cooper-Jacob method with upper drawdown zone data; $D$, for the Cooper-Jacob method with lower drawdown zone data.

The estimated storativity values from the NPS and USGS aquifer tests for the upper and lower drawdown zones were higher than expected for limestones and schists. The higher than expected storativity was likely the result of fractures increasing storage in the upper and lower drawdown zones of the aquifer; however, even considering secondary permeability and porosity from fractures, the estimated storativity values were still high. The duration of the aquifer test may have affected the accuracy of the storativity estimates. Relatively shorter duration aquifer-test methods provide less information about some aquifer properties, such as storativity (Butler, 2020). A longer duration aquifer test would provide additional data points for curve matching, which could increase the certainty of the storativity estimates.

\section{Hypothetical Equilibrium Drawdown}

The hypothetical equilibrium drawdown for the Burnpit well was estimated after the NPS aquifer test in 2009. The estimate was made by varying pumping rates and measuring water levels during pumping with the pump placed at about $500 \mathrm{ft}$ below land surface. Time-displacement curves from the different pumping rates were compared to estimate the capacity of the well to produce water at different pumping rates. Using data provided by the driller, the NPS estimated that the Burnpit well could maintain a pumping rate of 50 to $55 \mathrm{gal} / \mathrm{min}$ for 8 hours with a pump installed at a depth of $500 \mathrm{ft}$ below land surface. However, the sustainable yield of the Burnpit well was estimated by the NPS at no more, and possibly less, than $35 \mathrm{gal} / \mathrm{min}$ (table 1; Larry Martin, National 
Table 6. Single-well aquifer-test analytical results from curve-matching techniques applied to the upper and lower zones of the aquifer using early and late pumping data.

[NPS, National Park Service; gal/min, gallon per minute; USGS, U.S. Geological Survey; min., minute; ft²/d, foot squared per day]

\begin{tabular}{|c|c|c|c|c|c|}
\hline \multirow[b]{2}{*}{ Analytical method } & \multirow[b]{2}{*}{ Parameter (units) } & \multicolumn{2}{|c|}{2009 NPS test (20 gal/min) } & \multicolumn{2}{|c|}{2020 USGS test (27 gal/min) } \\
\hline & & $\begin{array}{l}\text { Upper drawdown } \\
\text { zone; early pump- } \\
\text { ing (15-25 min.) }\end{array}$ & $\begin{array}{l}\text { Lower drawdown } \\
\text { zone; late pumping } \\
\text { (30-194 min.) }\end{array}$ & $\begin{array}{l}\text { Upper drawdown } \\
\text { zone; early pumping } \\
\text { (5-11 min.) }\end{array}$ & $\begin{array}{c}\text { Lower drawdown } \\
\text { zone; late pumping } \\
\text { (14-186 min.) }\end{array}$ \\
\hline \multirow{2}{*}{$\begin{array}{l}\text { Theis (for unconfined } \\
\text { aquifer) }\end{array}$} & Transmissivity (ft²/d) & 9.0 & 11 & 7.7 & 10 \\
\hline & $\begin{array}{l}\text { Storativity } \\
\quad \text { (dimensionless) }^{1}\end{array}$ & 0.85 & 0.92 & 0.77 & 1.0 \\
\hline \multirow{2}{*}{$\begin{array}{l}\text { Cooper-Jacob (for } \\
\text { unconfined aquifer) }\end{array}$} & Transmissivity (ft²/d) & 22 & 14 & 9.7 & 12 \\
\hline & $\begin{array}{l}\text { Storativity } \\
\quad \text { (dimensionless) }^{1}\end{array}$ & 0.11 & 0.50 & 0.50 & 0.60 \\
\hline
\end{tabular}

${ }^{1}$ Storativity is equivalent to specific yield for this study.

Park Service, written commun., 2009). The NPS noted that the sustainable yield likely was overestimated because the water level did not stabilize during the 2009 NPS aquifer test. Data from longer aquifer testing could verify the estimated sustainable yield and provide NPS staff at the memorial a better yield estimate before integrating the well into the water distribution system.

Specific capacity is another measure of well capacity and is equal to the pumping rate divided by the water-level drawdown in the pumped well at a specific time (Hydrosolve, Inc., 2007). The specific capacity for the NPS aquifer test in 2009 was 0.16 gallon per minute per foot ([gal $/ \mathrm{min}] / \mathrm{ft})$ of drawdown at 3 hours, and the specific capacity for the USGS aquifer test in 2020 was 0.13 (gal/min)/ft of drawdown at 3 hours (table 1 ).

The rate of water-level recovery was calculated for the NPS and USGS tests by dividing the volume of water recovered in the well borehole after pumping ceased by the total recovery time and by the change in height of the water column during recovery. The water-level recovery rate was 0.017 and 0.013 (gal/min)/ft for the NPS and USGS aquifer tests, respectively. The rate of recovery slowed from about $10(\mathrm{gal} / \mathrm{min}) / \mathrm{ft}$ to less than 1 (gal/min)/ft after about 20 minutes for the NPS and USGS aquifer tests. The water-level recovery rate was nearly an order of magnitude less than the specific capacity estimated during pumping, indicating that water levels in the Burnpit well may not recover quickly enough during pumping to provide for a continuous source of water.

\section{Water Quality}

Water-quality samples were collected at the Burnpit well on June 24 and July 23, 2020, and analyzed for field-measured properties, major ions, metals, nutrients, and perchlorate. The samples were collected to examine the suitability of the well for drinking water or for other ancillary uses. Waterquality results are recorded in the USGS National Water
Information System database (U.S. Geological Survey, 2021) and summarized in table 7. Field properties, including water temperature, specific conductance, and $\mathrm{pH}$, were measured at about 15-minute intervals for 3 hours during well purging and before sample collection. Field properties stabilized and were recorded at the time of sample collection (table 7) and had specific conductance values of 465 and 447 microsiemens per centimeter at 25 degrees Celsius, temperature was 11.6 degrees Celsius, and $\mathrm{pH}$ values were 6.2 and 6.3 for the June 24 and July 23 sample dates, respectively. Dissolved oxygen was $3.0 \mathrm{mg} / \mathrm{L}$ for both sample dates, and turbidity was 300 and 84 nephelometric turbidity ratio units for the June 24 and July 23 samples, respectively.

Groundwater quality from the Burnpit well was compared to related drinking-water standards from the EPA (2021a, b) and to mean concentrations in previous samples collected from crystalline aquifers in the Black Hills (Williamson and Carter, 2002; table 7). Drinking-water standards established by the EPA are based on total (unfiltered) constituent concentrations, which refer to the combined concentrations of dissolved (filtered) and suspended phases of the water sample (Williamson and Carter, 2002). Samples collected as part of this study at the Burnpit well included analyses of dissolved and total constituent concentrations. Samples were analyzed for dissolved nutrients, dissolved and total major ions, and total trace metal concentrations, except for iron and manganese, which were analyzed for dissolved concentrations (table 7).

The Burnpit well water quality had similar field properties and concentrations of major ions (calcium, magnesium, sodium, and potassium) as other crystalline aquifer groundwater samples described by Williamson and Carter (2002). Concentrations of nutrients, cyanide, and total dissolved solids in samples from the Burnpit well were less than relevant EPA standards (table 7). Chloride concentrations from Burnpit well samples (about 75 and $81 \mathrm{mg} / \mathrm{L}$ ) were about seven times greater than the mean concentration from other crystalline 
Table 7. Water-quality data from samples collected at the Burnpit well (well 5) and relevant standards for comparison, June-July 2020.

[Bold text indicates value greater than U.S. Environmental Protection Agency standards. NWIS, U.S. Geological Survey National Water Information System; ID, identifier; NPDWR, National Primary Drinking Water Standard; SMCL, secondary maximum contaminant level; ${ }^{\circ} \mathrm{C}$, degree Celsius; --, not available; $\mu \mathrm{S} /$ $\mathrm{cm}$, microsiemens per centimeter at 25 degrees Celsius; NTRU, nephelometric turbidity ratio unit; mg/L, milligram per liter; N, nitrogen; <, less than; P, phosphorus; $\mathrm{SiO}_{2}$, silicon dioxide; $\mu \mathrm{g} / \mathrm{L}$, microgram per liter; E, estimated]

\begin{tabular}{|c|c|c|c|c|c|}
\hline \multirow{2}{*}{ Water-quality constituent } & \multicolumn{2}{|c|}{$\begin{array}{l}\text { Burnpit well (NWIS ID } \\
435240103265301 \text { ) }\end{array}$} & \multicolumn{2}{|c|}{$\begin{array}{c}\text { U.S. Environmental } \\
\text { Protection Agency standards }\end{array}$} & \multirow{2}{*}{$\begin{array}{c}\text { Mean concentration } \\
\text { from crystalline aquifers } \\
\text { in Black Hills, South } \\
\text { Dakota }^{3}\end{array}$} \\
\hline & $6 / 24 / 2020$ & 7/23/2020 & NPDWR ${ }^{1}$ & SMCL2 & \\
\hline Temperature, water, ${ }^{\circ} \mathrm{C}$ & 11.6 & 11.6 & -- & -- & 11 \\
\hline Specific conductance, $\mu \mathrm{S} / \mathrm{cm}$ & 465 & 447 & -- & -- & 387 \\
\hline Dissolved oxygen, mg/L & 3.0 & 3.0 & -- & -- & 5.5 \\
\hline Dissolved oxygen, percentage of saturation & 33 & 33 & -- & -- & -- \\
\hline $\mathrm{pH}$, standard units & 6.2 & 6.3 & & $6.5-8.5$ & 6.8 \\
\hline Turbidity, NTRU & 300 & 84 & -- & -- & -- \\
\hline Total dissolved solids, mg/L & 359 & 293 & -- & 500 & 293 \\
\hline Ammonia, filtered, $\mathrm{mg} / \mathrm{L}$ as $\mathrm{N}$ & $<0.01$ & 0.02 & -- & -- & -- \\
\hline Nitrite, filtered, $\mathrm{mg} / \mathrm{L}$ as $\mathrm{N}$ & 0.002 & 0.002 & 1 & -- & -- \\
\hline Nitrate, filtered, $\mathrm{mg} / \mathrm{L}$ as $\mathrm{N}$ & 0.403 & 0.403 & -- & -- & -- \\
\hline Nitrate plus nitrite, filtered, $\mathrm{mg} / \mathrm{L}$ as $\mathrm{N}$ & 0.405 & 0.405 & 10 & & 1.6 \\
\hline Orthophosphate, filtered, $\mathrm{mg} / \mathrm{L}$ as $\mathrm{P}$ & 0.005 & 0.008 & -- & -- & -- \\
\hline Cyanide, unfiltered, mg/L & 0.007 & $<0.005$ & 0.2 & -- & -- \\
\hline Hardness, mg/L as calcium carbonate & 190 & 180 & -- & -- & 172 \\
\hline Calcium, filtered, mg/L & 52.5 & 49.1 & -- & -- & 44 \\
\hline Calcium, unfiltered, $\mathrm{mg} / \mathrm{L}$ & 52.9 & 49.2 & -- & -- & -- \\
\hline Magnesium, filtered, mg/L & 14.0 & 14.0 & -- & -- & 15 \\
\hline Magnesium, unfiltered, $\mathrm{mg} / \mathrm{L}$ & 13.4 & 13.4 & -- & -- & -- \\
\hline Sodium, filtered, $\mathrm{mg} / \mathrm{L}$ & 14.6 & 13.8 & -- & -- & 10 \\
\hline Sodium adsorption ratio & 0.46 & 0.45 & -- & -- & 0.3 \\
\hline Potassium, filtered, $\mathrm{mg} / \mathrm{L}$ & 4.46 & 4.54 & -- & -- & 4 \\
\hline Chloride, filtered, $\mathrm{mg} / \mathrm{L}$ & 80.6 & 74.9 & -- & 250 & 11 \\
\hline Sulfate, filtered, mg/L & 9.09 & 9.01 & -- & 250 & 35 \\
\hline Fluoride, filtered, mg/L & 0.15 & 0.15 & 4 & 2 & 0.5 \\
\hline Silica, filtered, $\mathrm{mg} / \mathrm{L}$ as $\mathrm{SiO}_{2}$ & 33.4 & 33.4 & -- & -- & -- \\
\hline Arsenic, unfiltered, $\mu \mathrm{g} / \mathrm{L}$ & 282 & 814 & 10 & -- & 44.2 \\
\hline Barium, unfiltered, $\mu \mathrm{g} / \mathrm{L}$ & 125 & 98.3 & 2,000 & -- & 433 \\
\hline Copper, unfiltered, $\mu \mathrm{g} / \mathrm{L}$ & 16.5 & 5.5 & 1,300 & 1,000 & 430 \\
\hline Iron, filtered, $\mu \mathrm{g} / \mathrm{L}$ & 3,055 & 1,050 & -- & 300 & 267 \\
\hline Manganese, filtered, $\mu \mathrm{g} / \mathrm{L}$ & 66.6 & 50.9 & -- & 50 & 136 \\
\hline Strontium, unfiltered, $\mu \mathrm{g} / \mathrm{L}$ & 218 & 232 & -- & -- & ${ }^{4} 170$ \\
\hline Zinc, unfiltered, $\mu \mathrm{g} / \mathrm{L}$ & 1,554 & 1,290 & -- & 5,000 & ${ }^{4} 168$ \\
\hline Antimony, unfiltered, $\mu \mathrm{g} / \mathrm{L}$ & 0.13 & 0.06 & 6 & -- & -- \\
\hline Aluminum, unfiltered, $\mu \mathrm{g} / \mathrm{L}$ & 117 & 26 & -- & $50-200$ & ${ }^{4} 6.5$ \\
\hline Lithium, unfiltered, $\mu \mathrm{g} / \mathrm{L}$ & 62 & 56 & -- & -- & ${ }^{4} 17$ \\
\hline Perchlorate, filtered, $\mu \mathrm{g} / \mathrm{L}$ & 0.27 & Е 0.18 & -- & -- & -- \\
\hline
\end{tabular}

${ }^{1}$ U.S. Environmental Protection Agency (2021a).

${ }^{2}$ U.S. Environmental Protection Agency (2021b).

${ }^{3}$ Williamson and Carter (2002).

${ }^{4}$ Mean concentration from filtered samples. 
aquifer wells (11 mg/L), and sulfate concentrations from Burnpit well samples (about $9 \mathrm{mg} / \mathrm{L}$ ) were much less than mean concentrations from other crystalline wells (35 mg/L).

Several metals in the Burnpit well had concentrations greater than other crystalline aquifer wells in the Black Hills and EPA standards. Iron, zinc, and lithium concentrations for unfiltered samples in the well were at least three times greater than the mean filtered concentrations reported in Williamson and Carter (2002) for crystalline aquifers in the Black Hills. However, the concentrations of iron, zinc, and lithium from the samples collected in this study are reported as unfiltered, but the concentrations of trace metals reported in Williamson and Carter (2002) were for filtered samples. Manganese concentrations were less than the mean concentration for crystalline aquifers but exceeded the EPA secondary drinking-water standards. The iron concentration from the June 24 sample was about 11 times greater than EPA secondary drinking-water standards and mean concentrations from crystalline aquifers in the Black Hills. The groundwater sample collected on June 24, 2020, was more turbid with a rusty-iron color (even after purging) compared to the July 23 sample. The high iron concentration in the June 24 sample could be explained by the lack of use of the well for many years before sampling in 2020 . The iron could be sourced partly from the well casing and partly from the aquifer rock where oxygen-rich recharge from precipitation dissolved iron in the bedrock.

Arsenic concentrations in the Burnpit well samples collected in 2020 were greater than the EPA primary standards and the mean concentration for crystalline aquifers in the Black Hills. Arsenic occurs naturally in rock that composes crystalline aquifers (Williamson and Carter, 2002) and concentrations from samples in the Black Hills commonly exceed the 10 micrograms per liter $(\mu \mathrm{g} / \mathrm{L})$ EPA primary drinking-water standard. Arsenic concentrations from the Burnpit well were 282 and $81.4 \mu \mathrm{g} / \mathrm{L}$ for the June and July samples, respectively. The mean concentration of arsenic in crystalline aquifer wells in the Black Hills was $4.2 \mu \mathrm{g} / \mathrm{L}$ with a maximum concentration of $103 \mu \mathrm{g} / \mathrm{L}$ in samples collected through 1998 (Williamson and Carter, 2002).

High concentrations of arsenic, iron, and manganese metals in the Burnpit well make groundwater from the well in its natural state unusable for drinking water, and water treatment would be necessary to reduce the trace element concentrations to less than the EPA primary and secondary drinking-water standards. However, if memorial staff have immediate nonpotable water requirements, such as for construction and fire suppression, groundwater from the Burnpit well could provide water without causing additional stress to current (2021) drinking-water sources.

\section{Summary}

Mount Rushmore National Memorial (hereafter referred to as "the memorial”), in western South Dakota, is maintained by the National Park Service (NPS) and includes 1,278 acres of land in the east-central part of the Black Hills. An ongoing challenge for NPS managers at the memorial is providing water from sustainable and reliable sources for operations, staff, and the increasing number of visitors. From 1967 through 2010, well 3 was the primary water source, and in 2010, well 6 (referred to by NPS staff as "well 2") was completed to supplement the water provided by well 3 . The Burnpit well (well 5) was completed in 2008 to a depth of 580 feet in metamorphic (crystalline) rock. The well was intended to supplement existing water sources but was not integrated into the water distribution system and has remained unused since construction. In 2020, the U.S. Geological Survey (USGS) and NPS completed a hydrological study of the Burnpit well at the memorial to estimate the geological and hydraulic properties of the aquifer supplying the well and to measure the water quality of the groundwater from the well. The purpose of this study was to document the methods, data, and results from borehole analyses, two single-well aquifer tests, and water-quality sampling and analysis of the Burnpit well at the memorial. The study provides NPS staff and managers background information for assessing future uses for the well.

The hydrogeology of the memorial includes localized and noncontinuous aquifers. Aquifers in the Proterozoic igneous and metamorphic rocks of the Black Hills generally are referred to as crystalline aquifers. Crystalline rock generally has low permeability, and water-table (unconfined) conditions generally prevail where the fractures in the rock are saturated. Local precipitation provides the primary recharge to aquifers in the memorial. A mean annual precipitation of 19 inches provides enough recharge to maintain springflow, streamflow, and well production; however, mean annual precipitation of less than 15 inches could reduce spring discharge, cause streamflow to cease, and lower well productivity. The actual effect of low precipitation is unknown because continuous water-level and springflow data are not available.

Methods for data collection and analysis for the study included borehole and video camera analysis in 2020, aquifer testing by the NPS in 2009 and the USGS in 2020, and water-quality sampling in 2020. Borehole analysis used data from well logs and borehole camera video to document rock fractures that could facilitate groundwater flow to the well and to determine the analytical method for aquifer-testing analysis. Single-well aquifer tests by the NPS in 2009 and the USGS in 2020 estimated hydraulic properties of the aquifer by comparing data recorded during the aquifer test to theoretical curves from analytical solutions for idealized aquifers. Aquifer tests also provided data on the maximum sustainable pumping rate of the well. Water quality was analyzed by recording groundwater field properties, collecting water samples for laboratory 
chemical analysis, and comparing the results to drinking-water standards and mean concentrations for crystalline aquifers in the Black Hills.

Borehole camera video was useful for characterizing the aquifer providing groundwater to the Burnpit well, and camera video generally matched the lithology recorded in the well log. The aquifer providing groundwater to the well contained many fractures oriented horizontally and vertically, and some were observed in camera videos for several feet in length along the borehole wall. Quartz veins in the schist also provide additional fractures accommodating groundwater flow. Fractures recorded in the well log and observed with the borehole camera, including more than 20 less prominent fractures and rough sidewall areas, indicated a fractured aquifer. The fractures are the primary conduits for groundwater flow through the rock and into the well.

Transmissivity was estimated for the upper and lower drawdown zones at the Burnpit well using the Theis and Cooper-Jacob methods of curve fitting applied to time and water-level displacement data recorded during the NPS and USGS aquifer tests. Transmissivity for the NPS test using the Theis method was 9.0 and 11 feet squared per day $\left(\mathrm{ft}^{2} / \mathrm{d}\right)$ for the upper and lower drawdown zones, respectively. Using the Cooper-Jacob method, the transmissivity was 22 and $14 \mathrm{ft}^{2} / \mathrm{d}$ for the upper and lower drawdown zones of the aquifer, respectively. Transmissivity estimates from the USGS aquifertest data were similar to estimates from the NPS aquifer test. The Theis method, applied to the upper and lower drawdown zones of the aquifer, produced transmissivity estimates of 7.7 and $10 \mathrm{ft}^{2} / \mathrm{d}$, and the Cooper-Jacob method produced estimates of 9.7 and $12 \mathrm{ft}^{2} / \mathrm{d}$, respectively. The transmissivity estimates for the upper and lower drawdown zones were similar between the NPS and USGS aquifer tests, but one discrepancy was observed. The transmissivity estimates of the upper drawdown zone were about $2 \mathrm{ft}^{2} / \mathrm{d}$ less than the lower drawdown zone, except for the discrepancy of the NPS aquifer test using the Cooper-Jacob method where the upper drawdown zone was $8 \mathrm{ft}^{2} / \mathrm{d}$ greater than the lower drawdown zone. The transmissivity differences in the NPS test using the Cooper-Jacob method likely were caused by a curve-matching misfit from using manual curve matching.

Storativity (specific yield) estimated using the Theis method for the NPS aquifer-test data was 0.85 and 0.92 for the upper and lower drawdown zones of the aquifer, respectively. The Cooper-Jacob method applied to NPS aquifer-test data produced storativity estimates of 0.11 and 0.50 for the upper and lower drawdown zones, respectively. Storativity results from the USGS aquifer-test data were similar with the upper drawdown zone having a lower storativity than the lower drawdown zone. The Theis method applied to the USGS aquifer-test data estimated storativity values of 0.77 and 1.0 for the upper and lower drawdown zones, respectively. The Cooper-Jacob method estimated storativity of 0.50 and 0.60 for the upper and lower drawdown zones of the USGS aquifer test, respectively. The estimated storativity values from the NPS and USGS aquifer tests for the upper and lower drawdown zones were higher than expected for limestones and schists. The higher than expected storativity was likely the result of fractures increasing storage in the upper and lower drawdown zones of the aquifer, but the duration of the aquifer test also may have affected the accuracy of the storativity estimates. A longer duration aquifer test would provide additional data points for curve matching, which could increase the certainty of the storativity estimates.

The hypothetical equilibrium drawdown for the Burnpit well was estimated after the NPS test in 2009 at no more, and possibly less, than 35 gallons per minute. The NPS noted that the sustainable yield likely was overestimated because the water level did not stabilize during the NPS aquifer test. The specific capacity for the NPS aquifer test in 2009 was 0.16 gallon per minute per foot ([gal/min]/ft) of drawdown at 3 hours, and the specific capacity for the USGS aquifer test in 2020 was 0.13 (gal/min)/ft of drawdown at 3 hours. The rate of water-level recovery after pumping ceased was 0.017 and 0.013 (gal/min)/ft for the NPS and USGS aquifer tests, respectively. The water-level recovery rate was nearly an order of magnitude less than the specific capacity estimated during pumping, indicating that water levels in the Burnpit well may not recover quickly enough during pumping to provide for a continuous source of water.

Water-quality samples were collected at the Burnpit well on June 24 and July 23, 2020, and analyzed for field-measured properties, major ions, metals, nutrients, and perchlorate. Several metals in the Burnpit well had concentrations greater than other crystalline aquifer wells and U.S. Environmental Protection Agency (EPA) standards. Iron, zinc, and lithium concentrations for unfiltered samples in the well were at least three times greater than the mean filtered sample concentrations reported for crystalline aquifers in the Black Hills. Manganese concentrations were less than the mean concentration for crystalline aquifers but exceeded the EPA secondary drinking-water standards. The iron concentration from the June 24 sample was about 11 times greater than EPA secondary drinking-water standards and mean concentrations from crystalline aquifers in the Black Hills. Arsenic concentrations in Burnpit well samples collected in 2020 were greater than the EPA primary standards and the mean concentration for crystalline aquifers in the Black Hills. Arsenic occurs naturally in the rock composing crystalline aquifers, and concentrations from samples in the Black Hills commonly exceed the 10 micrograms per liter EPA primary drinking-water standard.

High concentrations of arsenic, iron, and manganese metals in the Burnpit well make groundwater from the well in its natural state unusable for drinking water, and water treatment would be necessary to reduce the trace element concentrations to less than the EPA primary and secondary drinking-water standards. However, if memorial staff have immediate nonpotable water requirements, such as for construction and fire suppression, groundwater from the Burnpit well could provide water without causing additional stress to current (2021) drinking-water sources. 


\section{References Cited}

Allegheny Instruments, 2021, GeoVision borehole video systems: Monterey, Virginia, Allegheny Instruments, 2 p., accessed January 2021 at https://alleghenyinstruments.com/ wp-content/uploads/2018/12/GeoVISION-Nano-Camera. pdf.

Anderson, T.M., Eldridge, W.G., Valder, J.F., and Wiles, M.E., 2019, Generalized potentiometric-surface map and groundwater flow directions in the Madison aquifer near Jewel Cave National Monument, South Dakota: U.S. Geological Survey Scientific Investigations Report 2019-5098, 16 p., accessed January 2021 at https://doi.org/10.3133/ sir20195098.

Barker, J.A., 1988, A generalized radial flow model for hydraulic tests in fractured rock: Water Resources Research, v. 24, no. 10, p. 1796-1804. [Also available at https://doi.org/10.1029/WR024i010p01796.]

Butler, J.J., Jr., 2020, The design, performance, and analysis of slug tests (2d ed.): Boca Raton, Florida, CRC Press, 266 p.

Carter, J.M., Driscoll, D.G., Williamson, J.E., and Lindquist, V.A., 2002, Atlas of water resources in the Black Hills area, South Dakota: U.S. Geological Survey Hydrologic Investigations Atlas HA-747, 120 p. [Also available at https://doi.org/10.3133/ha747.]

Cooper, H.H., Jr., and Jacob, C.E., 1946, A generalized graphical method for evaluating formation constants and summarizing well-field history: Transactions, American Geophysical Union, v. 27, no. 4, p. 526-534, accessed January 2021 at https://doi.org/10.1029/TR027i004p00526.

Darton, N.H., 1901, Preliminary description of the geology and water resources of the southern half of the Black Hills and adjoining regions in South Dakota and Wyoming: U.S. Geological Survey 21st Annual Report, pt. 4, p. 489-599.

Darton, N.H., 1918, Artesian waters in the vicinity of the Black Hills, South Dakota: U.S. Geological Survey Water-Supply Paper 428, 64 p. 1 pl. [Also available at https://doi.org/10.3133/wsp428.]

Darton, N.H., and Paige, S., 1925, Description of the central Black Hills: U.S. Geological Survey Folios of the Geological Atlas 219, 34 p., 7 pls. [Also available at https://doi.org/10.3133/gf219.]

DeWitt, E., Redden, J.A., Buscher, D.P., and Wilson, A.B., 1989, Geologic map of the Black Hills area, South Dakota and Wyoming: U.S. Geological Survey Miscellaneous Investigations Series Map I-1910, scale 1:250,000. [Also available at https://doi.org/10.3133/i1910.]
Driscoll, D.G., Carter, J.M., Williamson, J.E., and Putnam, L.D., 2002, Hydrology of the Black Hills area, South Dakota: U.S. Geological Survey Water-Resources Investigations Report 02-4094, 150 p. [Also available at https://doi.org/10.3133/wri024094.]

Eldridge, W.G., and Hoogestraat, G.K., 2021, Borehole video and aquifer test data for the Burnpit well, Mount Rushmore National Memorial, South Dakota, 2020: U.S. Geological Survey data release, https://doi.org/10.5066/P98OZQN9.

Fishman, M.J., ed., 1993, v. 93-125. Methods of analysis by the U.S. Geological Survey National Water Quality Laboratory-Determination of inorganic and organic constituents in water and fluvial sediments, U.S. Geological Survey Open-File Report, 217 p. [Also available at https://doi.org/10.3133/ofr93125.]

Fishman, M.J., and Friedman, L.C., 1989, Methods for determination of inorganic substances in water and fluvial sediments (3d ed.): U.S. Geological Survey Techniques of Water-Resources Investigations, book 5, chap. A1, 545 p. [Also available at https://doi.org/10.3133/twri05A1.]

Garbarino, J.R., and Struzeski, T.M., 1998, Methods of analysis by the U.S. Geological Survey National Water Quality Laboratory_-Determination of elements in whole-water digests using inductively coupled plasma-optical emission spectrometry and inductively coupled plasma-mass spectrometry: U.S. Geological Survey Open-File Report 98-165, 101 p. [Also available at https://doi.org/10.3133/ ofr98165.]

Graham, J., 2008, Mount Rushmore National Memorial Geologic Resource Evaluation Report: Denver, Colo., National Park Service, Natural Resource Report NPS/ NRPC/GRD/NRR—2008/038, accessed December 2020 at https://irma.nps.gov/DataStore/DownloadFile/426459.

Heath, R.C., 1983, Basic ground-water hydrology: U.S. Geological Survey Water-Supply Paper 2220, 86 p. [Also available at https://doi.org/10.3133/wsp2220.]

Hoogestraat, G.K., and Rowe, B.L., 2016, Perchlorate and selected metals in water and soil within Mount Rushmore National Memorial, South Dakota, 2011-15: U.S. Geological Survey Scientific Investigations Report 2016-5030, 29 p., accessed January 2021 at https://doi.org/10.3133/sir20165030.

Hydrosolve, Inc., 2007, AQTESOLV for WindowsUser's guide (ver. 4.5): Reston, Va., 529 p., accessed December 2020 at http://www.aqtesolv.com/download/ aqtw20070719.pdf. 
Kruseman, G.P., and de Ridder, N.A., 1994, Analysis and evaluation of pumping test data (2d ed.): Wageningen, Netherlands, International Institute for Land Reclamation and Improvement Publication 47, 370 p., accessed March 2021 at https://www.hydrology.nl/key-publications/93-analysisand-evaluation-of-pumping-test-data.html.

Moench, A.F., 1984, Double-porosity models for a fissured groundwater reservoir with fracture skin: Water Resources Research, v. 20, no. 7, p. 831-846. [Also available at https://doi.org/10.1029/WR020i007p00831.]

National Oceanic and Atmospheric Administration, 2020, Daily summaries station details: National Climatic Data Center, accessed December 2020 at https://www. ncdc.noaa.gov/cdo-web/datasets/GHCND/stations/ GHCND:USC00395870/detail.

National Park Service, 2020, Park statistics-Mount Rushmore National Memorial South Dakota: National Park Service web page, accessed December 2020 at https://www.nps.gov/moru/learn/management/statistics.htm.

Page, L.R., and others, 1953, Pegmatite investigations 1942-1945, Black Hills, South Dakota: U.S. Geological Survey Professional Paper 247, 229 p., accessed January 2021 at https://doi.org/10.3133/pp247.

Patton, C.J., and Kryskalla, J.R., 2011, Colorimetric determination of nitrate plus nitrite in water by enzymatic reduction, automated discrete analyzer methods: U.S. Geological Survey Techniques and Methods, book 5, chap. B8, 34 p. [Also available at https://doi.org/10.3133/tm5B8.]

Powell, J.E., Norton, J.J., and Adolphson, D.G., 1973, Water resources and geology of Mount Rushmore National Memorial, South Dakota: U.S. Geological Survey Water-Supply Paper 1865, 50 p., 1 pl. [Also available at https://doi.org/10.3133/wsp1865.]

Putnam, L.D., Hoogestraat, G.K., and Sawyer, J.F., 2008, Water-quality effects and characterization of indicators of onsite wastewater disposal systems in the east-central Black Hills area, South Dakota, 2006-08: U.S. Geological Survey Scientific Investigations Report 2008-5232, 115 p. [Also available at https://doi.org/10.3133/sir20085232.]

Rahn, P.H., 1990, Ground-water recharge at Mount Rushmore: Proceedings of the South Dakota Academy of Science, v. 69 , p. $129-138$.

Redden, J.A., and DeWitt, E., 2008, Maps showing geology, structure, and geophysics of the central Black Hills, South Dakota: U.S. Geological Survey Scientific Investigations Map 2777, 44-p. pamphlet, 2 sheets. [Also available at https://doi.org/10.3133/sim2777.]
Redden, J.A., Saxton, S.L., Terry, M.P., and Fahrenbach, M.D., 2016, Geologic map of the Mount Rushmore Quadrangle, South Dakota: South Dakota Department of Environment and Natural Resources, Quadrangle Map 26, scale 1:24,000, accessed December 2020 at http://www.sdgs.usd.edu/pubs/ pdf/GQ24K-26_2016.pdf.

Schaap, B.D., 2000, Aquifer test to determine hydraulic properties of the Elm aquifer near Aberdeen, South Dakota: U.S. Geological Survey Water-Resources Investigations Report 00-4264, 28 p. [Also available at https://doi.org/10.3133/ wri004264.]

Stallman, R.W., 1978, Aquifer-test design, observation, and data analysis: U.S. Geological Survey Techniques of WaterResources Investigations, book 3, chap. B1, 31 p.

South Dakota Department of Environment and Natural Resources, 2020, Water well completion reports: South Dakota Department of Environment and Natural Resources, 2 p., accessed December 2020 at https://denr.sd.gov/wrimage/WellCompletionReports/images15k/00002650.pdf.

South Dakota Department of Environment and Natural Resources, 2021, Search for South Dakota water rights: South Dakota Department of Environment and Natural Resources web page, accessed January 2021 at https://denr.sd.gov/des/wr/dbwrsearch.aspx.

South Dakota Mines, 2021, Aquifers-Introduction: South Dakota Mines web page, accessed February 1, 2021, at https://www.sdsmt.edu/aquifers/.

Theis, C.V., 1935, The relation between the lowering of the piezometric surface and the rate and duration of discharge of a well using groundwater storage: Transactions - American Geophysical Union, v. 16, no. 2, p. 519-524, accessed January 2021 at https://doi.org/10.1029/ TR016i002p00519.

U.S. Department of Agriculture, 2020, Geospatial Data Gateway: U.S. Department of Agriculture digital data, accessed December 2020 at https://datagateway.nrcs.usda.gov/GDGHome_DirectDownLoad.aspx.

U.S. Environmental Protection Agency, 2007, Method 6860-Perchlorate in water, soils and solid wastes using ion chromatography/electrospray ionization/mass spectrometry: U.S. Environmental Protection Agency, 31 p., accessed December 2, 2015, at https://www.epa.gov/sites/production/ files/2015-12/documents/6860.pdf.

U.S. Environmental Protection Agency, 2021a, National Primary Drinking Water Regulations: U.S. Environmental Protection Agency web page, accessed January 29, 2021, at https://www.epa.gov/ground-water-and-drinking-water/ national-primary-drinking-water-regulations. 
U.S. Environmental Protection Agency, 2021b, Secondary drinking water standards-Guidance for nuisance chemicals: U.S. Environmental Protection Agency web page, accessed January 29, 2021, at https://www.epa.gov/sdwa/ secondary-drinking-water-standards-guidance-nuisancechemicals.

U.S. Geological Survey, 2021, USGS water data for the Nation: U.S. Geological Survey National Water Information System database, accessed January 29, 2021, at https://doi.org/10.5066/F7P55KJN.

U.S. Geological Survey, [variously dated], National field manual for the collection of water-quality data: U.S. Geological Survey Techniques of Water-Resources Investigations, book 9, chaps. A1-A9, accessed January 23, 2013, at https://

pubs.water.usgs.gov/twri9A.

Williamson, J.E., and Carter, J.M., 2002, Water-quality characteristics in the Black Hills area, South Dakota: U.S. Geological Survey Water-Resources Investigations Report 01-4194, 202 p. [Also available at https://doi.org/10.3133/ wri20014194.]
For more information about this publication, contact: Director, USGS Dakota Water Science Center 821 East Interstate Avenue, Bismarck, ND 58503 1608 Mountain View Road, Rapid City, SD 57702 605-394-3200

For additional information, visit: https://www.usgs.gov/centers/ dakota-water

Publishing support provided by the

Rolla Publishing Service Center 
